\title{
Fee Complexity and Investor Mistakes in Retail Financial Markets
}

\author{
Bige Kahraman*
}

\begin{abstract}
Mutual funds sold via brokers offer fund portfolios that investors can purchase in one of three classes: A, B or C. These classes are distinguished only by their fee schedules and thus have different net performance results. An analysis of relative class performances for a set of U.S mutual funds between 1992 and 2008 reveals a striking fact about class B: while classes A and $\mathrm{C}$ provide the best performance results at long and short holding periods, respectively, class $\mathrm{B}$ is dominated by either class $\mathrm{A}$ or $\mathrm{C}$ at any holding period. The inferiority yet popularity of class $\mathrm{B}$ at first suggests that naïve investors who do not understand the fee schedule of this class are being exploited. However, I propose two hypothetical clienteles which might rationally demand class B shares: one (a) with uncertain holding periods, or one (b) that desires to have long holding periods but is unable to commit to them. I identify whether investors rationally or naïvely purchase class B by examining the flow-fee sensitivity and estimating investor holding periods. My results support the naïve investor explanation.
\end{abstract}

\footnotetext{
* Said Business School, University of Oxford. E-mail: bige.kahraman@sbs.ox.ac.uk.

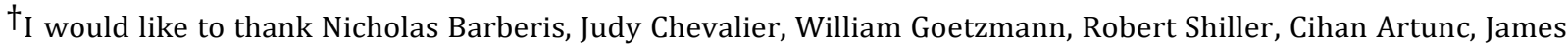
Choi, Abhiroop Mukherjee, Stefan Lewellen, Guillermo Ordonez, Salil Pachare, Heather Tookes and seminar participants at Yale University for helpful discussions. I gratefully acknowledge financial support from Whitebox Advisors and thank Financial Research Corporation for sharing their report on fund distribution industry. All remaining errors are my own. An earlier version of this paper was previously circulated under the title of "Do Mutual Fund Brokers Exploit Investors through their Fee Schedules?"
} 


\section{Introduction}

Some mutual fund companies distribute their shares to retail investors through brokers who market funds and provide advisory services to investors. These funds offer claims to their portfolios through a menu of fee schedules. Each fee schedule corresponds to a distinct "class" of share, typically named A, B, or C. All investors earn the same gross returns, but each class receives different returns net of fees. The multiple class structure gives investors several payment options, but it also complicates their decisions. Industry commentators and regulatory bodies express concerns that the complexity of class B schedules confuses some investors and may be used by brokers to shroud their high expenses. ${ }^{1}$ Their arguments are generally based on the casual observation that there are limited, if any, circumstances under which class B is preferable to classes A or C, which are suitable for investors with long and short holding periods, respectively. Thus, it is puzzling why class $\mathrm{B}$ has been quite popular among investors. ${ }^{2}$

In this paper, I study how different investor clienteles select into classes A, B, or C. Particularly, I ask whether class $B$ attracts rational investors, who are better off with it for reasons that are not immediately apparent, or it attracts naïve investors, who are unable to assess the fund expenses correctly. In spite of the debate about class B in the marketplace and the growing academic interest in understanding the costs and benefits of mutual fund brokers (for example, Bergstresser et al. [2009], Christoffersen et al. [2013], Guercio and Reuter [2014], Del Guercio et al. [2010], Foerster et al [2017]), only a few papers (e.g., Nanda et al. [2009]) have studied the studied the fee schedules of broker-sold mutual funds. None of these studies have yet investigated whether the complexity of the fee schedules offered by broker-sold mutual funds lead to investor mistakes and exploitation. My paper aims to fill this gap, providing substantive examination of an important policy question with implications for public welfare.

Fee schedules for classes A, B and C can be summarized as follows. Class A represents the traditional method of payment. This class includes an annual fee and a "front load", a sales charge deducted when the investor makes his purchase. Classes B and C were initiated in the mid 1990s to offer clients alternative payment options. Class B offers a schedule with several features. The most prominent one allows investors to delay sales charges through a "back-end load" payable upon redemptions, typically within the first six years. Also, this class imposes higher annual fees. Class $\mathrm{C}$ varies, however it generally has no loads but an annual fee equivalent to that of class $\mathrm{B}$.

I begin my analysis by first establishing performance differences across classes: (a) classes A and $\mathrm{C}$ are consistently optimal for investors with long (seven years or more) and short holding periods, respectively, and (b) class B is almost always dominated by either class A or C for an investor who knows his investment horizon with certainty. Based on these results, I suggest that

\footnotetext{
${ }^{1}$ E.g., Financial Industry Regulatory Authority (FINRA) Investor Alert, "Class B Mutual Fund Shares: Do the Make the Grade?", October 11, 2008. http://www.finra.org/investors/protectyourself/investoralerts/mutualfunds/p005975.

2 Figure 1 shows the year-end total net assets, in billions, managed in each class $\mathrm{A}, \mathrm{B}$ and $\mathrm{C}$ for funds in my sample between 1995 and 2008. The sample includes diversified U.S equity mutual funds which offer classes A, B and C. Until 2003, class B constitutes a substantial fraction of total fund assets such as 35-40 percent. The total value of assets in class B amount to $\$ 92$ and $\$ 128$ billion in 1999 and 2003 billion, respectively. However, in the later period, assets in class B decline, for example, to $\$ 57$ billion in 2007 , making only about 16 percent of total fund assets.
} 
rational investors with long and short holding periods select into classes A and C, respectively. To explain why investors might be purchasing class B despite its domination by the other classes, I offer three hypotheses. My first two hypotheses provide rational justifications of investor behavior, while the final hypothesis poses that brokers exploit the mistakes of naïve investors.

The first hypothesis indicates that class B is optimal for investors who consider holding shares for both long and short periods. This follows from my finding that this class frequently performs second best at each holding period while the other classes have either the best or worst performance. Therefore, investors with uncertainty in their holding periods might demand class B. The second hypothesis suggests that investors who are willing to but unable to commit to a long investment horizon choose class B. These investors prefer class B to class A even though they are aware of its inferiority because they value the back-end load as a commitment device. My final hypothesis proposes investor naïveté as the source of demand. Based on Ellison and Ellison [2009], this hypothesis argues that exploitation may have resulted from the increasing competitive pressure on brokers due to new developments in fund distribution methods during the last decade. The Class B fee structure might be used by brokers to exploit investors who are known to be "too" averse to front loads and inattentive to annual fees (Wilcox [2003]).

The second part of my analysis offers three tests to distinguish between rational and naïve investor behavior. First, I directly test whether class B fund flows are sensitive to fees or not, as suggested by rational and naïve investor hypotheses, respectively, after controlling for fund attributes which might be valued by investors. I test my hypotheses by examining the differences in the estimated coefficients of fund flows on fees across classes of the same fund, because of a potential upward bias in the fee coefficients due to unobservable fund attributes (for example, quality of customer services). Since such unobservable attributes are specific to the fund rather than to the class, biases arguably cancel out when I examine the differences across the classes of the same fund. If investors rationally purchase class B, I expect no differences between the fee coefficients across classes. However, if it is the naïve investors who demand class B without realizing its expenses, I expect that fund flows are less sensitive to fees for class B only.

Second, I offer a simple model to estimate investors' holding periods using data on annual fund inflows and outflows. I test whether holding periods of class B investors are consistent with the uncertain holding period hypothesis. Performance analysis shows that, for the demand for class B to be rations, it should be the case that class $B$ investors hold their shares for less (greater) than seven years more often than class A (C) investors and less often than class C (A) investors. Furthermore, I test if back-end loads impede redemptions during the holding periods in which a back-end load is imposed, as predicted by the commitment device hypothesis.

The findings of this paper support the naïve investor hypothesis. I find that class B flows are significantly less sensitive to fees, while there are no differences between flow-fee sensitivities of classes A and C. In addition, class B investors have holding periods that are inconsistent with both rational hypotheses. Contrary to the uncertain holding period hypothesis, they are in fact less (more) likely to redeem their shares in the short (long) term compared to the other classes of investors. Moreover, they tend to leave the fund frequently during the holding periods in which a back-end load applies. 
This paper contributes to burgeoning literature in household finance which focuses on investor decisions in mutual fund selection. An important puzzle in mutual fund investor behavior is the prevalence of high-fee funds that provide no benefits in terms of return performance. There are two competing views that aim to explain this phenomenon. One view, the rational view, argues that high-fee funds offer some unobservable benefits (e.g., customer services, financial advice) that investors value. Using a structural model, Hortacsu and Syverson (2004) provide some evidence for this view in the context of US index funds. An alternative, the behavioral view, however, emphasizes that investor confusion about complex fee schedules is the main culprit of the demand for high-fee mutual funds. My findings contribute to this debate by providing evidence from mutual funds' class B fee schedules. Overall, the findings complement the experimental studies which show that households commonly make mistakes in minimizing fund expenses (e.g., Wilcox [2003], Choi et al. [2010]). Moreover, the results are consistent with Guercio and Reuter [2014], who show that broker-sold funds have weak incentives to generate value for their clients, and with Anagol and Kim [2012], who show evidence for shrouded fees in the context of Indian closed-end funds.

At a broader level, the analysis of this paper also adds to the literature on how rational firms strategically set their fees in the presence of naïve clients (for example, DellaVigna and Malmendier [2004], Gabaix and Laibson [2006], Carlin [2009], Ellison and Wolitzky [2012], Christoffersen and Musto [2002]) by providing evidence from the mutual fund industry. Echoing the message of DellaVigna and Malmendier [2006], the findings of the paper highlights that imposing the rational expectations hypothesis on observed choice data can potentially lead us to infer preferences incorrectly.

Over the past years, the National Association of Securities Dealers (NASD) has charged several brokerage firms with class B sales abuses. ${ }^{3}$ Shortly thereafter, a number of fund companies closed their class Bs, or imposed restrictions on brokers' sales in this class. ${ }^{4}$ These developments have raised, amongst many industry practitioners and commentators, the question of whether these restrictions engender inefficiencies by leading to the disappearance of a useful product that benefits certain investors, or they protect naïve investors and thus improve public welfare. The findings of this paper provide an academic view to these discussions.

Section 2 provides background information. Section 3 describes the data. Section 4 documents new findings on classes A, B and C. Section 5 discusses the hypotheses. Section 6 presents the empirical analysis. Section 7 details robustness checks. Section 8 concludes.

\section{Background Information 5}

\footnotetext{
3 For more information: “Investors Beware: The Problem with Class B shares", September 2t8, 2010 (sponsored by the Hayes law firm). http://www.aboutbrokerfraud.com/b_shares/.

${ }^{4}$ For example, the number of class Bs in my sample declines to 571 in 2008 from 807 in 2005 . Furthermore, among the existing ones, about 100 of them close to the new investors during this period.

${ }^{5}$ Information in this section is obtained from papers published by the Investment Company Institute (Reid [2000], and Rea and Reid [2003]), Fabozzi [2002] and Morningstar [2006]. More detailed information on fund distribution industry is included in the appendix.
} 


\subsection{Evolution of Fund Distribution}

Mutual funds traditionally distributed shares to investors through two channels. Funds sold either through brokers who helped with marketing and advised investors (advice channel) or directly to investors with no advisory services (direct channel). All funds, irrespective of their distribution channels, charged annual fees called "expense ratios". To cover their advisory services, the advice channel funds imposed higher annual fees and a sales charge called a "front load", which investors paid when they purchase their shares. Commonly, funds in advice and direct channels are referred to as load and no-load funds, respectively, in the marketplace.

Starting from early 1990s, alternative distribution methods, which provided retail investors cheaper access to funds, gained importance. The most dramatic change has been the rapid growth of the retirement channel due to the increasing popularity of employer-sponsored pension plans. Retirement assets as a share of total mutual fund assets, for example, increased from 19 percent in 1990 to 35 percent in 1999. In addition, fund companies and fund distributors expanded distribution channels beyond the traditional direct and advice channels. Among these new channels, fund 'supermarkets' attracted several investors by offering the convenience of purchasing no-load funds from a number of fund families at low costs. ${ }^{6}$ Other nontraditional channels, which include financial advisors, mutual fund wrap programs, banks and variable annuities, have also become increasingly popular. Similar to traditional advice channel brokers, independent financial advisors also offer advisory services, but these charge an asset- based fee instead of a load for their services.

As demand was shifting towards these new channels, the traditional advice channel initiated new sales strategies following the adoption of Rule 18f-3 by the Securities and Exchange Commission (SEC) in 1995. This rule simply allowed brokers (and fund companies) to offer multiple "classes" of the same product in which each class would be defined as a claim on the same underlying fund portfolio with a different fee schedule. Shortly thereafter, traditional advice channel funds introduced alternatives to the front load through new classes. The introduction of new classes perhaps helped brokers resist increasing competition in fund distribution to some degree, but they could not preserve their market shares. Among the long-term funds that are sold through a third party, the share of the traditional advice channel has declined from 59 percent in 1990 to 35 percent in $1999 .{ }^{7}$ Also, a recent analysis by the Financial Research Corporation on mutual fund market sizing expects further contraction in this channel for the next five years and views the channel at the edge of extinction. ${ }^{8}$

\subsection{Classes A, B and C}

Mutual funds sold via brokers (advice channel) typically offer three fund classes which are labeled A, $B$ and $C$. Even though there are no formal definitions of these classes, the fee schedule of these classes is very similar across funds. Table 1 illustrates an example of the fee schedule for a traditional advice

\footnotetext{
${ }^{6}$ Schwab, introduced in 1992, is the first mutual fund supermarket.

${ }^{7}$ Reid [2000], figure 8

8 "Mutual Fund Market Sizing, 2007-2012". I thank Financial Research Corporation for sharing this report with me.
} 
channel fund with classes A, B and C. Expense ratios have two components including the management and $12 \mathrm{~b}-1$ fees, which are used to cover portfolio administration costs and distribution expenses, respectively. We first see in Table 1 that management fees are distributed equally across classes. The classes differ, however, in their loads and in the levels of $12 b-1$ fees.

Class A represents the traditional means of payment in the advice channel including a front load. Class As generally offer front load reductions at particular investment levels, starting, usually, at $\$ 25,000$ or $\$ 50,000$ and up to $\$ 1,000,000$, at which point the load is often eliminated al- together. Also, some class As do not require investors to pay the necessary amount upfront to qualify for a load reduction, but only over time by signing a letter of intent.

Class B introduces a new type of sales charge called a "back-end load" which imposes a gradually declining load on withdrawal, typically within the first 6 to 7 years. For example, a "5,4,3,3,2,1,0" back-end load imposes a 5 percent load on the relevant amount if the investor withdraws after holding the shares for a year, a 4 percent load after two years, and so on. Class Bs differ by the price which they impose on the back-end loads. SEC rule 6c-10 restricts them to three options: initial offer price, the sale price or the minimum of the two. In addition to the back-end load, class B includes a $12 \mathrm{~b}-1$ fee which is higher than that of class A. However, if investors hold their shares long enough, $12 \mathrm{~b}-1$ fees are reduced to the level of class $\mathrm{A}$. There is no standard required holding period for a $12 \mathrm{~b}-1$ reduction, but most funds lower this fee after eight to ten years. ${ }^{9}$

Class $\mathrm{C}$ commonly has only a $12 \mathrm{~b}-1$ fee, which tends to be about as high as that of class $\mathrm{B}$. However, unlike class $B$, class $C$ does not offer a reduction in $12 \mathrm{~b}-1$ fees over time. Also, some class Cs charge low back-end loads, as in the example in Table 1, which mostly defer in 1 or 2 years.

The investing public does not observe the contract between brokers and fund companies. Therefore, we do not know which party chooses the fee schedules and how brokers are compensated for their services. Generally, it is thought that brokers receive the loads and part of $12 \mathrm{~b}-1$ fees.

\section{Data}

\subsection{Data Construction}

I obtain data on mutual funds from two sources: The Center for Research in Security Prices Survivorship-Bias-Free U.S. Mutual Fund Database (CRSP) and Mutual Fund Links (MF Links). CRSP provides the history of each mutual fund class's name, expense ratio, $12 \mathrm{~b}-1$ fees, front and back-end loads, total net assets, returns, and class status on its availability to new investors, and starting from 2000, the institutional and retail class indicators. I complement the data with the Investment Company Data Institute (ICDI) investment objective codes.

All the information reported in CRSP is for each class of each fund. I match CRSP with MF Links, which allows me to observe different classes of the same fund. MF Links concentrates on domestic equity funds. The matching rate between MF Links and CRSP is approximately 92

\footnotetext{
${ }^{9}$ Morningstar Inc., indicate that only 13 percent of all class Bs decrease their expense ratios before the end of the eighth year.
} 
percent in this universe. The unmatched domestic equity funds are mainly small, defunct and new funds (as of April 2008).

CRSP does not indicate the class types (for example, A, B and C). However, if the fund has multiple classes, the class type is specified in the reported name. For example, class A of the Morgan Stanley S\&P 500 Index fund is titled "Morgan Stanley S\&P 500 Index; class A shares". I decompose the fund name to collect information on class type. As funds offer a separate class for their institutional clients and also report it in their name, my decomposition allows me to construct an institutional class indicator. ${ }^{10}$ I cross check my institutional class indicator with that of CRSP for after 2000. I find these two to be highly consistent; therefore, I complement the CRSP indicators with mine for missing observations.

\subsection{Sample}

I pick funds that offer retail classes $\mathrm{A}, \mathrm{B}$ and $\mathrm{C}$ with fee schedules that are consistent with the descriptions in Section 2. The rule allowing multiple classes was adopted in 1995, but some funds obtained exemptions earlier, therefore, my sample spans the years between 1992 and 2008. I exclude classes that are closed to new investors and funds with inconsistent ICDI codes across their classes. I require each fund to have complete information on all fees for all three classes. Finally, similar to prior mutual fund studies, I restrict the analysis to diversified U.S. equity mutual funds. Hence, I choose funds with ICDI codes of AG (aggressive growth), GI (growth and income) and LG (long-term growth).

The data do not indicate the distribution channel. However, the Investment Company Institute factbooks and various industry anecdotes indicate that classes A, B and C are typically offered by brokers in the traditional advice channel. ${ }^{11}$ Thus, I will assume that classes A, B and C in my sample are sold through these brokers.

One potential concern might be that funds offer these classes also in other distribution channels, (for example, a 401(k) plan, an independent advisors program, or brokers) with a fee structure that is different from what is observed in the data. Using data on fund distribution channels from 1996 to 2002, Del Guercio et al. [2010] document that funds do not typically use multiple distribution channels to offer their shares to retail investors. Therefore, to address the potential problem that some of my class A, B and C observations are also sold in multiple distribution channels, I drop the nonretail A, B and C classes from my sample.12

\section{$4 \quad$ New Facts}

In this section, I ask which class is ex-ante optimal, given an investor's holding period and in- vestment amount. I study holding periods from 1 to 15 years and initial investment amounts of $\$ 50,000$,

\footnotetext{
10 The institutional classes are either called class I, Y, or use abbreviations such as Inst, Instl or Institutional in their name. In the institutional class classification, I also include classes sold through the retirement channel. These classes commonly appear as Z, R, K, 529 and AARP.

${ }^{11}$ See Rea and Reid [2003], page 2. For more anecdotes, see Reid [2000] and Fabozzi [2002].

12 In this way, I exclude 5.5 percent, 3.2 percent and 1.9 percent of observations for classes A, B and C, respectively
} 
$\$ 100,000, \$ 250,000, \$ 500,000$, and $\$ 1,000,000$, as these are the most common breakpoints for front load reductions.

\subsection{Relative Class Performance}

I carry out my analysis using a sample of funds that offers all three classes A, B and C. The final sample includes 13,923 (4,641 of each class) observations of 909 different funds. I first seek to answer the question from the perspective of a risk neutral investor. Hence, I compare net expected returns across classes of the same fund, for each holding period and investment amount.

I conduct my analysis under three assumptions. First, investors understand that classes belong to the same underlying portfolio, so that each class receives the same gross returns. Second, investors use current fees to predict future fees. ${ }^{13}$ Third, all class Bs lower expense ratios at the end of the eighth year. In fact, many funds take between 8 to 10 years; the third assumption therefore leads to an overestimation of the expected returns on class B shares for holding periods longer than 7 years.

Funds are allowed to choose which price back-end loads are imposed on: sale price, initial offer price, or the minimum of the two. I express the net expected return calculation based on each case, respectively, as follows:

$$
\begin{aligned}
& \left.E_{t}\left(r_{n}\right)=\left(1-\text { front }_{t}\right)(1-(\text { expratio } t))^{n}\left(1-\text { (backend }_{t, n}\right)\right) E_{t}\left(R_{n}\right) \\
& E_{t}\left(r_{n}\right)=\left(1-\text { front }_{t}\right)(1-(\operatorname{expratio} t))^{n} E_{t}\left(R_{n}\right)-\left(\text { backend }_{t, n}\right) \\
& E_{t}\left(r_{n}\right)=\left(1-\text { front }_{t}\right)(1-(\text { exp ratio } t))^{n} E_{t}\left(R_{n}\right)-E_{t}\left(\text { backend }_{t, n} \min \left\{1, R_{n}\right\}\right)
\end{aligned}
$$

where $r_{n}$ and $R_{n}$ are the cumulative net (of fee) and gross return, respectively, for an n-year holding period, front $t$ is the front load, (exp ratiot) is the expense ratio, and (backend $\left.d_{t, n}\right)$ is the back-end load for redeeming shares in $n$ years. In the case of class A (B and C), backend $_{n}\left(\right.$ front $_{t}$ ) is set to zero.

For a class B investor, (3) is the most cost effective under any expectations of future fund re- turns. If the investor expects positive growth in fund gross returns, he estimates the net expected return to be lower when back-end load is applied to the sale price, that is, under (1), as he expects the future sale price to be greater than the initial offer price. Since a back-end load applies to re- demptions for the first 6 (or 7) years only, the price it is imposed on matters for net expected return calculations for holding periods less than 6 (or 7) years.

Since I do not observe the price that back-end loads are imposed on, I use the same calculation for each class B observation. I first focus on (1) since, unlike (2) and (3), it allows me to assess the relative performance of classes without any distributional assumptions on investors' beliefs about future fund returns . I refrain from making these assumptions for the sake of robustness. The drawback of using (1), however, is that I might be underestimating the net expected returns to some class B for holding periods less than 6 to 7 years. This might then inaccurately generate the dominance of other classes

\footnotetext{
13 Given the persistence in fees (Carhart [1997]), I believe this is a reasonable assumption.
} 
over class B for these periods. However, in the next section, I show that main conclusions do not depend on the net expected return specification.

For each fund-year observation, I assign the winner, middle and loser class based on relative class performances at holding periods from 1 to 15 years and at each investment amount. Table 2 reports the distribution of the winner class across classes A, B and C separately for each holding period and for each investment amount.

For investments of less than $\$ 50,000$, classes $A$ and $C$ are typically the winners for holding periods of more and less than 7 years, respectively. For example, for a holding period of 5 (9) years, class $\mathrm{C}$ (A) is a winner for 96.06 (81.49) percent of fund-year observations. For a seven year holding period, the distribution of the winner class is almost uniform across classes, $(22.19,35.68$, and 42.12 for class $\mathrm{A}, \mathrm{B}$ and $\mathrm{C}$ respectively). However, except for the seven-year holding period, Class $\mathrm{B}$ barely appears as a winner class. In spite of my third assumption, which overestimates the net expected returns to class B for more than 8 years, this class still wins for only about 17 percent of fund-year observations for these holding periods. For investments greater than or equal to $\$ 50,000$, class $A$ offers load reductions. This results in sharp improvements in class A performance, which leads to the outperformance of this class starting from 3 to 4 years. In this case, the frequency that class B wins drops to less than 1 percent for each holding period.

To better gauge the differences in relative performances, I rank the classes in descending order within fund-year observation and examine the distribution of ranks for classes A, B and C. Table 3 reports the median of ranks for each class. Even though class B is hardly ever a winner at any holding period, it is commonly the middle class for investments less than $\$ 50,000$ (except for 4 years). However, for higher investment amounts, class B is dominated by both classes A and C for holding periods of less than 7-8 years.

For consistency with the rest of the analysis, I restrict attention to domestic equity funds. My results remain the same if I include class A, B and C funds across all objective styles. I report results for the full sample period, 1992 to 2008 , but the conclusions hold for each year separately as well.

In sum, I find that class B is almost never ex-ante optimal for an investor, with any investment amount, who knows his/her investment horizon with certainty. Classes $\mathrm{A}$ and $\mathrm{C}$ are, however, frequently ex-ante optimal for investors with long and short holding periods, respectively. For investments less than $\$ 50,000$, a long (short) holding period is one that is greater (less) than seven years. For these investment levels, while class B is outperformed by one of classes A or C, it is not outperformed by both classes. More precisely, it outperforms class A for short and class A for long holding periods. However, for larger investments, as front load reductions make class A more competitive for short holding periods, both classes dominate class $B$ for holding periods less than seven years. These findings are robust to the price on which class Bs impose the back-end loads, to taxes, and to the investor's preference for risk and time.

\subsection{Robustness}

\subsubsection{How the back-end load is imposed}


My results are largely independent of the assumption regarding the price on which back-end loads are imposed. For short holding periods, class B is still outperformed by class $\mathrm{C}$ because class B differs from class $C$ only by the level of the back-end load. Hence, the net expected returns to class $B$ are always lower than those of class $\mathrm{C}$ by at least the value of the back-end load. For longer holding periods, the results again do not depend on the specification because the back-end load is only imposed for holding periods less than 6 years. Therefore, class B remains the middle class for relatively small investments. Finally, for large investments, since load reductions provide class $A$ expected net returns high enough to outperform $C$ between 3 and 7 years, class B is outperformed by both classes for these holding periods, as before.

The only results from Tables 2 and 3 that may not hold under (2) and (3) are the relative performance of classes $A$ and $B$ from 1 to 3 years. For these holding periods, while class $C$ is the winner class, in spite of the load reductions, class B can be either the loser or the middle class depending on the size of load reductions and investors' expectations of future gross returns. For example, if the investor is optimistic enough, the load reductions might not be enough to result in the dominance of class A over B, or vice versa.

\subsubsection{Taxes}

I investigate the implications of taxes for my results. Mutual fund investors are required to pay taxes on their realized investment income. This can be earned in two ways: if an investor sells his shares, or if funds pass dividends and capital gains realizations through to investors as required by tax law. Loads and other commissions are not tax deductible but are taken into account while calculating the gains and losses from sales. ${ }^{14}$ Therefore, investor's tax considerations from the sale of shares do not change relative performance as the expected tax bill is equal to the investor's tax rate multiplied by the net expected return. However, the second component of taxes might poten- tially alter rankings if funds distribute dividends and capital gains unequally across classes. While funds have no legal obligation to distribute dividends and gains across classes in a particular way, it is their fiduciary responsibility to distribute equally to all shareholders. Consistent with this, I observe in the data that differences between the reported capital gains and dividends across classes $\mathrm{A}, \mathrm{B}$ and $\mathrm{C}$ are negligibly small and insignificantly different from zero. Therefore, I conclude that tax considerations do not affect my results. ${ }^{15}$

\subsubsection{Time and Risk Preference}

A risk averse agent cares not only about the expectation of net return but also about its standard deviation. Under my assumptions in Section 4.1, the fee adjustment on gross return is a multi-

\footnotetext{
${ }^{14}$ Internal Revenue Services 550, chapter 3

15 Tax regulations allow investors to deduct the expenses of producing taxable investment income (IRS publication 564), which might include the fund's expense ratios. Therefore, class B and C investors might pay less taxes on dividends and gains realizations since they pay higher expense ratios than class A investors. However, regulations also state that these expenses are only deductible if they are greater than 2 percent of adjusted gross income. Since this is a high threshold, only few investors most likely qualify for it.
} 
plicative constant which simply scales down the expectations and standard deviations. Therefore, relative class performances are the same as before, from the perspective of a risk averse agent. Time preference also does not alter the conclusions because any discount factor enters the net expected return calculation multiplicatively, having no impact on relative performances.

\section{Hypotheses}

\subsection{Demand for Class B}

In this section, I discuss three hypotheses to describe the investor clientele that select into class B. The first two hypotheses suggest that investors with (a) uncertain holding periods, or (b) long holding periods and commitment problems rationally choose class B. The final hypothesis argues that naïve investors, who can not judge the fund expenses correctly, flock into this class.

\subsubsection{Uncertain Holding Period}

In the optimality assessment, I considered two types of investors: investors with long holding periods and investors with short holding periods. This may be a natural classification since we expect investors to know whether they will hold the shares for relatively long or short periods, even if they do not know exactly when they will liquidate. This hypothesis proposes another type of investor: the "uncertain" investor who considers holding his shares for both short and long holding periods with corresponding probabilities. Investors might have such preferences for several reasons - for instance, due to uncertainty about the arrival of personal liquidity shocks or future fund (or market) returns. This hypothesis neither questions nor examines the sources of this preference. In Section 4, we saw that, for small investments, class B is frequently the middle class for all holding periods while the other classes are either a winner or loser class at short and long holding periods (defined relative to seven years). This suggests that, even though class B performs worse than the other classes at both long or short holding periods, it might be ex-ante optimal given the distribution function the uncertain investor has over holding periods.

I also noted that for large investments, class B frequently has the worst performance between 3 and 7 years due to load reductions. Therefore, it is unlikely that class B would be the optimal class for an investor with a large investment even if he is uncertain about his holding period. Therefore, this hypothesis requires that class B investors have small enough investments not to qualify for a load discount.

\subsubsection{Back-end Load as a Commitment Device}

The behavioral economics literature draws attention to individuals' commitment problems. It suggests that sophisticated individuals who correctly perceive their future time-inconsistent behavior might seek commitment devices to constrain their future actions (for example, Laibson [1997]). In addition, rational firms might rationally respond to to the demand for commitment devices in their contract and pricing schemes (DellaVigna and Malmendier [2004]). 
Back-end loads are imposed when investors redeem their shares. Thus, if investors perceive it as a punishment, back-end loads might have an additional value as a commitment device. ${ }^{16}$ This hypothesis suggests that sophisticated investors who are willing to keep the shares for long holding periods but suffer from commitment problems choose class B, even though they are aware of its underperformance relative to class $\mathrm{A}$.

\subsubsection{Naïve Investor Hypothesis}

Several surveys and experimental studies indicate two common investor mistakes. First, investors self-report that they are not attentive to expense ratios (for example, Capon et al. [1996], Alexander et al. [1998]). Belsky and Gilovich [1999] argue that investors tend to disregard the significance of expense ratios, which range from as low as 1 percent to more than 3 percent, because people commonly fail to take small numbers seriously. In addition, when choosing among different combinations of front loads and and expense ratios, investors tend to weight front loads more than expense ratios in a way that is inconsistent with their self-reported expected holding periods (Wilcox [2003], Dominitz et al. [2008]). Based on Kahneman and Tversky [1979] and Thaler [1985], Wilcox [2003] suggests that investors might be more averse to front loads than expense ratios if front loads are coded as immediate losses and ongoing expenses as small subtractions from the larger gain of the fund return. Consistent with this evidence, Barber et al. [2005] document that there has been a decreasing demand for U.S equity mutual funds with high front loads, but not expense ratios, between 1970 and 1999. They contend that over time investors have become increasingly aware of and averse to front loads since these are more salient than expense ratios.

Therefore, this hypothesis suggests that some investors might be mistakenly choosing class B instead of $A$ if they fail to take into account higher expense ratios and their impact over a long period, and (or) if they are too averse to front loads. Also, since class B is the first mutual fund product which includes a back-end load, investors might not easily realize this load if they do not read the prospectus carefully, or if fund companies and brokers do not advertise it. Not realizing the back-end loads and higher expense ratios, some investors in fact might purchase this class believing that they are purchasing a no-load fund. These mistakes are not mutually exclusive and I do not attempt to distinguish between them.

We do not observe whether the fund companies, brokers, or both together choose the fee schedules. Fund companies might have initiated class B for investors who would be better off with it, as I suggested in the previous subsections, but brokers might abuse the class. Alternatively, fund com- panies and (or) brokers may knowingly offer this class to exploit naïve investors. My hypothesis does not uncover the primary intentions of brokers or fund company executives. It only argues that incentives to exploit, in either way, might be the result of competition dynamics which have changed adversely for mutual funds sold via brokers.

As discussed in Section 2, over the last decade, fund distribution has become highly competitive

16 While both front and back-end loads might serve as commitment devices, a back-end load might be considered more effective than the front load if investors perceive front loads as sunk costs. 
with the inception of new channels that provide investors alternative and cost-effective methods to buy funds. For example, investors can purchase funds through a supermarket or a 401(k) plan by only paying considerably lower expense ratios. Also, investors who like to receive advisory services have the option to choose between a traditional broker and an independent financial ad- visor who does not charge any loads but an asset-based fee. Therefore, since brokers (and their fund companies) are less likely to attract sophisticated investors who do not value their services as much without further decreasing their fees, they might target naïve investors. As these investors are averse to front loads, inattentive to annual fees and unfamiliar with back-end loads, it might be easier to sell them class B (for example, by mischaracterizing the class as a "no-load" fund) and impose higher expenses. Therefore, collusion on exploitation might arise as such collusion allows all funds sold via brokers to make the sales that they could not otherwise make and earn extra profits. ${ }^{17}$

I offer this intuition based on the behavioral industrial organization literature which challenges the classical economic theory that firms are always willing to fully inform customers of their products, especially in competitive markets (for example, Milgrom [1981]). For instance, Ellison and Wolitzky [2012] and Carlin [2009] argue that all (or some) firms in an industry might collectively choose obfuscation strategies, which refer to various sale or pricing tactics aimed at con- fusing households about product features and key price components. The firms might be employing these strategies to keep overall industry mark-ups high. Contrary to the classical view, these papers predict that incentives to obfuscate customers increase as competition increases. Ellison and Ellison [2009] provide evidence for such an outcome from the online shopping industry. The authors suggest that online retailers intentionally make shopping complicated because recent improvements in online search technologies lead to a Bertrand-like competition that decreases mark-ups and retailers' ability to cover their high fixed costs. I believe the case of class B is analogous to that of Ellison and Ellison [2009] since brokers also have fixed costs for advertising and providing ongoing advisory services and face considerable competitive pressure.

\section{Empirical Tests}

\subsection{Net Flow - Fee Analysis}

In this section, I distinguish between rational and naïve behavior of class B investors by assessing the sensitivity of flows to fees. The hypotheses based on rationality and naïveté make distinct predictions: the former predicts a negative relation between flows and fees while the latter predicts no (or a weak) relation, after controlling for fund attributes that might influence fund purchase decisions. I restrict attention to the relation between net flow and expense ratios since, unlike loads, expense ratios have

\footnotetext{
17 Given that class C could also be easily marketed as a no-load fund, it might not be immediately apparent why brokers choose class B as the exploitation device. I believe the answer lies in brokers' compensation schemes. Information on brokers' compensation is not publicly available. However, as long as they receive some pro rata share of loads and expense ratios charged within each class, I can predict that brokers would choose to direct naïve investors to class B if they are sufficiently impatient or do not expect investors to keep the shares long enough to qualify for a reduction in the expense ratios offered in class B.
} 
enough variation to examine. (Table 4 and 5).

I perform my test on the differences in the flow-fee sensitivities across classes $\mathrm{A}, \mathrm{B}$ and $\mathrm{C}$ of the same fund, to avoid a potential upward bias in the estimated coefficient of flows on expense ratios due to unobservable attributes such as the quality of customer services and fund visibility. Since unobservable attributes are fund rather than class specific, differences in the coefficients on expense ratios between classes $\mathrm{A}, \mathrm{B}$ and $\mathrm{C}$ (offered by the same funds) is expected to be free of bias. Based on my findings presented in Section 4, I suggest that rational investors with long and short holding periods demand class A and C, respectively. Therefore, the rational hypotheses for class B investors predict no differences across classes in flow-fee sensitivities, however, the naïve investor hypothesis predicts that class B net flows are less sensitive to expense ratios compared to the other classes. Results confirm the naïveté hypothesis.

\subsubsection{Empirical Strategy}

A strand of the mutual fund literature suggests that fees and fund returns are not the sole determinants of fund demand since investors' tastes for non-portfolio characteristics and search frictions also play a vital role in fund choices (for example, Hortacsu and Syverson [2004], Sirri and Tufano [1998]). A partial list of non-portfolio characteristics include the quality of customer services, the manager's reputation, the fund's tax management strategies, and the fund family characteristics. Also, funds that have a star ranking, and that belong to a large family, or to a family with a star fund ranking are suggested to attract more flows as they are more visible to investors (Sirri and Tufano [1998], Huang et al. [2007], Nanda et al. [2004], Guercio and Tkac [2009]).

Non-portfolio characteristics and fund visibility are largely unobservable. This leads to an omitted variable bias problem in reduced form specifications of fund demand as funds choose their fees given, or simultaneously with, their attributes. Strategic fee setting is complex; however, the direction of bias is likely to be upward since funds with more favorable attributes are likely to charge higher fees. Therefore, without controlling for these unobservable, I might not be able to distinguish naïve fee insensitivity from investors' appraisal of certain fund attributes.

I offer a strategy that allows me to circumvent this problem within a reduced form framework. My strategy relies on the observation that differentiation in visibility and non-portfolio characteristics are at the fund level rather than at the class level. Therefore, I pick a sample of funds which offer all A, $\mathrm{B}$ and $\mathrm{C}$ classes so that the distribution of visibility and non-portfolio characteristics across funds within each class is similar. Then, I test the predictions of my hypotheses by looking at cross-class differences in fee sensitivities. ${ }^{18}$ In this way, the interpretation of the results is no longer ambiguous. As biases are similar across classes, they cancel out when I take the differences. While the rational hypotheses predict no significant differences in fee sensitivities across classes, the investor naivete hypothesis predicts that class B flows are significantly less sensitive to expense ratios.

Classes A, B and C are arguably similar in their non-portfolio characteristics and visibility because investors in these classes are shareholders to the same fund and the same family, and moreover, they

\footnotetext{
18 I do not use fund fixed effects to control for unobservable fund characteristics because I believe that these characteristics are likely to be time variant. For example, a fund might become visible after a stellar performance and media attention.
} 
are sold via the same brokers. Therefore, all classes have the same manager, are entitled to the same tax management policy, have access to any program or service offered by the fund and fund family, and receive advisory services.

\subsubsection{Empirical Model}

In this section, I run a fixed-effects regression to estimate the differences in fee sensitivities across classes A, B and C based on the following model

$$
\begin{aligned}
\text { NetFlow }_{c, i, t}= & a+b_{1} \text { ExpenseRatio }_{c, i, t-1}+b_{2} \text { ExpenseRatio }_{c, i, t-1} * B+b_{3} \text { ExpenseRatio }_{c, i, t-1} * C \\
& +b_{4} \text { Load }_{c, i, t-1}+b_{5} \text { Load }_{c, i, t-1} * B+b_{2} \text { Load }_{c, i, t-1} * C+\text { Year Dummies } \\
& + \text { Style Dummies }+F E_{c, i}+e_{c, i, t}
\end{aligned}
$$

where $c, i$ and $t$ indicate class, fund and year, respectively. Control variables include Perf, square of Perf, $\log (T N A)$ and $\log$ (AssetsinSameClass). $B(C)$ is an indicator variable that equals 1 if the observation is a class $B(C)$ and zero otherwise. I use class-fund fixed effects, $F E_{c, i}$, to account for the unobservable variation in class features since these are likely to be correlated with fees. As explained in Section 2, for example, class Bs vary by which price they impose back-end loads on, some class Cs charge back-end loads while others do not and some class As require investors to sign a letter of intent to qualify for a front load discount. I include year and objective style dummies to control for aggregate shocks and cluster standard errors by fund to allow for serial correlation in residuals due to fund specific shocks. The dependent variable, NetFlowi,t, is the growth in total assets under management net of internal growth, as a percentage of initial assets; that is,

$$
\operatorname{NetFlow~}_{i, t}=\frac{T N A_{i, t}-T N A_{i, t-1}\left(1+R_{i, t}\right)}{T N A_{i, t-1}}
$$

where $R_{i, t}$ is the annual return (including reinvestment and dividends) of fund $i$ in year $t$ and $T N A_{i, t}$ is fund i's total net asset value (in millions) at the end of year $t$. By adopting this definition, I am assuming that money comes in (or goes out) at the end of each year. Following Huang et al. [2007], I winsorize the top and bottom 2.5 percent tails of the net flow variable to remove errors associated with mutual fund mergers and splits documented by Elton et al. [2001].

The main coefficients of interest are the ones for expense ratios. Since funds publicize the expenses of the previous fiscal year, I use year $t-1$ values of fees as explanatory variables. For funds with fiscal years that do not end in December, I take the last fees published before the end of the year. Following the literature, I take the load variable as the maximum of any type of load applies. For example, in the case of class $\mathrm{A}$, it is equal to the front load at the first breakpoint. It is set to zero for a class $\mathrm{C}$ that do not charge any back-end loads. Within each class, loads are quite similar in the cross section, and highly persistent in time series. Thus, I cannot estimate the impact of loads on net flows but this variable simply captures the difference in average growth rates of net flow across classes during my sample period (Figure 1).

I control for past performance at various time lags to distinguish the well-established perfor- mance 
chasing behavior from fee sensitivity since performance is reported to the public net of expense ratios (Chevalier and Ellison [1997]). As in Spiegel and Zhang [2010], my measure of performance, Per $f$, is the differ- ence between a fund's raw return and the average return of funds with the same objective style. Following Chevalier and Ellison [1997], I include year $t, t-1$, and $t-2$ past performance and the square of year $t-1$ performance.

Some fund families offer programs allowing investors to exchange shares of any class of a fund for the same class of any other fund within the family at low or no cost. Such programs might generate investor demand that is not necessarily as sensitive to fees. Investors in each class would have access to the program, however the impact of the program on net flows might be different across classes of the same fund since fund families might differ in their distribution of total assets managed in each class. Therefore, I include as an explanatory variable the natural logarithm of total family assets held under each class, $\log$ (Assets In Same Class) ${ }_{i, t}$, to control for flows that come from the other funds of the same class within same family; this is different from the literature.

\subsubsection{Results}

Results are reported in Table 6. In column (1), I estimate the model including the logarithm of class age and the standard deviation of raw monthly returns; it is standard to control for these in net flow regressions. The monthly return standard deviation proxies for a fund's perceived riskiness and the logarithm of age captures the differences in fund growth rates based on age. I present results of the model without these controls in column (2).

As in previous studies, age and logarithm of $T N A_{t-1}$ are negatively related to net flow, and monthly return standard deviation does not show any significant relation. As expected, the logarithm of total family assets in the same class is significantly and positively related to net flow suggesting that part of fund flows arrive from other funds within the same family. Consistent with the literature on performance chasing behavior, I find that year $t-1$ and $t-2$ performance are strong predictors of net flow. Contemporaneous return, on the other hand, is not significantly related, but the sign of the coefficient is in the expected direction. Also, there is a significant neg- ative relationship between the square of year $t-1$ performance and net flow. This finding might, at first, be surprising given that many studies (for example, Sirri and Tufano [1998], Chevalier and Ellison [1997]) document a convex relationship under a variety of definitions for either flows or past performance. However, my results are in line with Del Guercio et al. [2010], who document that investors in the broker channel respond to intermediate (style-adjusted) past returns. They show that it is primarily the direct channel funds that have a convex relationship between fund flows and performance. I do not further examine estimates of the square of $t-1$ performance as Spiegel and Zhang [2010] argues that regressions with net flow as the dependent variable are not appropriate candidates for nonlinearity tests.

I focus on the coefficients of ExpenseRatiot ${ }_{-1} x B$ and ExpenseRatiot ${ }_{-1} x C$. Both columns (1) and (2) show that net flows are significantly less negatively related to expense ratios for class $B$ with p-values of 0.03 and 0.02 , respectively. There is no significant difference between classes A and C. 
In column (3), I also allow investors in each class to differ in past performance chasing behavior by interacting Perf $f_{t-1}$ with class B and C dummies. Similar to Nanda et al. [2009], I find net flows for class $C$ to be significantly more sensitive to past performance in period $t-1$ relative to other classes. However, this behavior does not alter my results. The difference in the expense ratio coefficient between classes B and A is still significant with a p-value of 0.022 , and there is no such difference between classes $\mathrm{A}$ and $\mathrm{C}$.

I also estimate the model in column (3) without fixed effects since the naïve investor hypothesis might not necessarily require fixed effects in the case of strategic fee setting with naïve investors. The results are reported in column (4). While the sizes of the coefficients are substantially different in the regressions without fixed effects, I still find that the coefficients on the interaction terms between the expense ratio and the class dummies are significantly positive ( $p$ value of 0.03 ) for class $B$, and not significantly different from zero for class C.

As most class Bs experience demand reversals after 2006, perhaps following the NASD investigations, class B net flows become more frequently negative. If outflows are not related to fees, then greater average outflows to class Bs might drive down the coefficient on expense ratio for this class. However, it is also possible that investors are leaving the class because they are learning about its fees. Since they are likely to leave the more expensive ones, the increasing number of investor redemptions in the later periods might force a negative relationship between expense ratio and net flow for class B. Therefore, the way in which an increase in outflows affects the coefficient on expense ratio is not obvious. Still, I repeat the analysis in column (3) on the subperiod before 2007 and report the results in column (5). Differences in the expense ratio coefficient between A and B are estimated to be similar to (3) and still significantly different from zero with a p-value of 0.037 . In sum, I conclude that the flow-fee sensitivity analysis provides evidence in favor of the naïve investor hypothesis.

\subsection{Estimating Holding Periods}

In this section, I offer a simple model to estimate the distribution of average investor holding periods. I examine whether class A (C) investors have holding periods greater (less) than seven years, and whether observed holding periods for class B are consistent with either the uncertain holding period or commitment device hypotheses.

The uncertain holding period hypothesis argues that class B investors put considerably positive weights on both short and long holding periods. Since class A and C investors are expected to heavily weight holding periods less and greater than seven years, respectively, this hypothesis make the following two predictions. First, investors in class B are more (less) likely to keep their shares less than seven years compared to the investors in class A (C). Second, they are likely to liquidate than class C(A) investors at holding periods greater than seven years. The commitment device hypothesis, on the other hand, predicts low liquidation probabilities for class $\mathrm{B}$ at holding periods where a back-end load applies, which is typically 6 (rarely 7) years. In this section, I test whether the estimated holding periods are consistent with these predictions. 


\subsubsection{Model}

I begin with presenting the intuition behind my model through a simple example. Consider a fund initiated at the beginning of this year that immediately attracts two investors, $\mathrm{A}$ and $\mathrm{B}$, with dollar investment amounts of in $f l o w^{A}$ and in $f l o w w^{B}$. Suppose that the fund did not receive any other inflow throughout the year and each investor has a discrete distribution function over holding periods of 1 to $n$ years. I denote the liquidation probabilities at each holding period by $p^{i}=$

$\left(p_{1}^{i}, \ldots, p_{n}^{i}\right)$, where $i=A, B$, such that $p_{j} \geq 0$ and $\sum_{j=1}^{j=n} \underset{j}{n}=1$. Under the assumption that purchase and liquidation decisions are made at the beginning of each year, I can then express the expected total dollar outflows in the next year as:

$$
E_{t} \llbracket\left(\text { Outlof } w \rrbracket_{t}\right)=p_{1}^{A} \operatorname{Inflow}_{t-1}^{A}\left(1+r_{t-1}\right)+p_{1}^{B} \operatorname{Inflow}_{t-1}^{B}\left(1+r_{t-1}\right)
$$

where $r_{t-1}$ is the fund net return in year t-1. I multiply inflows by $r_{t-1}$ to account for the growth in the money after the initial purchases. Since total inflow, In flow, is the sum of each investor's inflows, I rewrite (6) as:

$$
E_{t} \llbracket\left(\text { Outlof } w \rrbracket_{t}\right)=p_{1}^{w} \operatorname{Inflow}_{t-1}\left(1+r_{t-1}\right)
$$


where $p_{1}^{w}$ is the average liquidation probability weighted by the investors' share of total dollar inflows. Similarly, under the same assumptions, I can express the expected outflows for a two- yearold fund as:

$$
E_{t}\left(\text { Outflow }_{t}\right)=\beta^{w} \operatorname{Inflow}_{t-1}\left(1+r_{t-1}\right)+\beta^{w} \operatorname{Inflow}_{t-2}\left(1+r_{t-2, t}\right)
$$

since outflows include inflows from the previous year and also from the year before, with the weighted average probability of $p^{w}{ }_{2}$ As before, I multiply In flow $w_{t-2}$ by the cumulative fund return from year to $t-2$ to $t, r_{t-2, t}$, to account for the growth in the money in two years. Hence, for an n-year-old fund, the expected outflows are:

$$
E_{t}\left(\text { Outflow }_{t}\right)=\sum_{s=1}^{s=n} p_{s}^{w} \operatorname{Inflow} w_{-s}\left(1+r_{t-s, t}\right)
$$

I extend the insight from this simple example to derive a model that estimates average liquidation probabilities by decomposing the annual outflows to past annual inflows.

From the information available in CRSP, I can only deduce net flows, which are at a monthly frequency starting from 1990. I estimate the annual inflow and outflow using the monthly net flows. My measure of annual dollar inflow (outflow) is the (absolute value of) sum of monthly positive (negative) net dollar flows in a given year. Hence, my measure of annual inflow (outflow) only includes monthly inflows (outflows) in excess of monthly outflows (inflows) in months with net inflows (outflows).

$$
\begin{gathered}
\text { \$n flow }=\sum_{m=1}^{m=12}\left(\$ \text { NetFlow }_{m, t}\right) \mathbf{1}\left\{\$ \text { NetFlow }_{m, t}>0\right\} \\
\$ \text { Outflow } \\
=\sum_{m=1}^{m=12} \mid \$ \text { NetFlow }_{m, t} \mid \mathbf{1}\left\{\$ \text { NetFlow }_{m, t}<0\right\}
\end{gathered}
$$


where $\$ N e t F l o w_{m, t}=T N A_{m, t}-T N A_{m, t}\left(1+r_{m, t}\right)$. To calculate annual inflows and outflows, I require at least 10 months of non-missing net flows in the data. As before, I winsorize the top and bottom 2.5 percent tails of my measures.

I acknowledge that these measures can be somewhat noisy. A priori, it is not obvious how substantial the noise is: it depends on the timing of inflows and outflows. For example, in the case where new money comes in and goes out in distinct months, my measures are in fact equal to the true values. However, in the case where inflows and outflows balance out every month, my measures are equal to zero, and are unable to identify inflows and outflows. In other cases, inflows and outflows are always underestimated to some extent. The magnitude of the noise is likely to vary across observations. However, there seems to be no reason for the distribution of inflows and outflows within a year across months to be correlated with any fund characteristics. Hence, I assume that the noise is independent.

I report summary statistics on monthly dollar net flows in panels 1 and 2 of Table 7 . Panel 1 shows that for my sample period, net dollar flows are almost equally likely to be positive or negative. However, as expected, class B has more frequently negative net dollar flows (58 percent). In panel 2, I report the average numbers of months with positive and negative net dollar flows within a year. On average, about 6 months within a year have positive or negative net dollar flows.

CRSP do not provide data on inflows and outflows, but the N-SAR filings, which funds are required to file semi-annually, report monthly dollar inflows and outflows at the fund level. Cashman et al. [2008] present summary statistics on monthly fund inflows (and outflows) as a percentage of previous month-end total fund assets, based on NSAR data. ${ }^{19}$ I compare my measures to theirs for a similar sample they use. To facilitate the comparisons, I scale my dollar measures by previous monthend total assets and aggregate at the fund level. Descriptive statistics are presented in Table 7, panel 3. Funds in my sample have lower monthly proportional net flows than theirs. This implies that proportional monthly inflows and outflows are also likely to be small for my sample funds.20 Therefore, I compare the ratios of proportional net flow to proportional inflow and outflows. While my measures underestimate true values, they seem to capture some part of inflows and outflows. For instance, in NSAR, the ratio of average proportional inflows (outflows) to average proportional net flows is equal to 2.7 (1.7), while with my measures this ratio is equal to 2 (0.9).

I next investigate the implications of the timing assumptions. In my example, I assume that investors leave or arrive only at the beginning of the year. However, it is likely that purchases and sales occur throughout the year. In this case, the rate of return that applies to each inflow will be different. To correct for the differential rate of return due to differences in arrival time, I refine my annual inflow measure as follows:

\footnotetext{
${ }^{19}$ Funds report in NSAR at the aggregate level, that is, summing the dollar inflows and outflows of all classes.

20 With my measures, inflows and outflows appear as a smaller proportion of previous month-end total assets. For example, Cashman et al. [2008] document that in NSAR, inflows (outflow) on average constitute 5.4 percent (3.4 percent) of asset size. In my sample, I find this fraction to be about 2 percent ( 0.09 percent) with my measures.
} 


$$
\$ \text { Inflow }_{t}=\sum_{m=1}^{m=12} \$ \text { NetFlow }_{m, t} 1\left\{\$ \text { NetFlow }_{m, t}>0\right\}\left(1+r_{m+1,12, t}\right)
$$

where $r_{m, 12, t}$ is the cumulative monthly return from month $m$ to the end of the year. I sum the year end dollar amount of each monthly inflow, which is equal to the monthly inflow multiplied by the cumulative monthly fund return, from the end of the arrival month of the inflow to the end of the year. Hence, the equation (12 )to be estimated can be written as:

$$
\begin{gathered}
\text { \$Outlofws } s_{i, t}=\sum_{s=1}^{s=10} p_{s}^{w} \text { \$Inflow } \text { I }_{i, t-s}\left(1+r_{t-1-s}\right)+\$ \text { Inflow }_{i, t} \\
+ \text { Year Dummies }+ \text { Style Dummies }+e_{i, t}
\end{gathered}
$$

I choose a discrete distribution function over annual holding periods for convenience. It is computationally burdensome to estimate another version of this model which allows liquidations at shorter intervals (for example, months), due to drastic increase in the number of parameters. Since most classes A, B and C were initiated after the mid 1990s, I restrict the support of the distribution function to 10 years to have a sufficiently long panel. In estimating (13), I include year and objective style dummies to control for dependence across observations due to aggregate level shocks that might force systematic unexpected early or late liquidations. In addition, I control for \$ In f lowt because of the mechanical correlation between contemporaneous outflow and inflow measures. Inclusion of $\$$ In flowt only has an impact on the coefficient on $\$$ In $f$ low $w_{-1}$ due to serial correlation between these two. Hereafter, I will use $p_{s}$ instead of $p^{w}$ notation for expositional purposes.

\subsubsection{Sample}

I choose retail classes A, B and C that are open to investors, are at least 10 years old and have all the data necessary for calculating the annual inflows and outflows. To increase the power of my tests, I include funds in all objective styles in this analysis. My final sample has 2,693 observations for A, 1,632 for B and 707 for C. Hence, I have relatively more power for classes A and B. Sample periods are from 2001 to 2008 for A and from 2002 and 2008 for B and C.

\subsubsection{Results}

For each class, I first run an OLS regression of equation (13) without imposing any restrictions on coefficients. I cluster standard errors by class-fund. Results are reported in panel 1 of Table 8. Among the thirty coefficients of past inflows I estimate (ten for each class), all except two ( $\$$ In flowt-1 for class B and \$ In f lowt-5 for class $\mathrm{C}$ ), are positive and less than one. Moreover, coefficients for each class sum to close to $1(0.814,1.01,0.804$ for A, B and C). These numbers thus are consistent with my 
model, which defines these coefficients as probabilities.

Panel 1 indicates that the average holding period of 7 years is quite high and significant for each class. This is in line with the common practice in the literature which assumes a 7-year hold- ing period. The assumption in the literature is based on the redemption rates published by the Investment Company Institute in 1991 (Sirri and Tufano [1998]). Thus, my findings suggest that average investor redemption behavior did not change substantially in the more recent period.

I find that investors in class $\mathrm{C}$ have significantly high liquidations within seven years, and class $\mathrm{A}$ investors are more likely to hold shares for more than 7 years than class $C$ investors. However, class A investors also liquidate in earlier years, for example in year 3 and 5. In Section 3, I documented that for large investments, class A is the winner class starting from holding periods of 3 years. Since my model estimates the weighted (with investor's share in total dollar inflows) average of investors' liquidation probabilities, coefficients in early years might therefore primarily reflect the shorter holding periods of these investors. Finally, I observe that class B investors predominantly sell their shares in 2 to 8 years in an almost uniformly fashion.

Next, I estimate the model requiring coefficients of $\$ \operatorname{In}$ flowt-1 to $\$ \operatorname{In} f l o w_{t-10}$ to be positive and add up to 1. Results are reported in panel 2 of Table 8. Once I impose restrictions, I obtain different estimates, but conclusions from panel 1 carry forward. To test for the uncertain holding period hypothesis, I construct two test statistics which are equal to the sum of coefficients of past dollar inflows from year $t-1$ to $t-6$ and year $t-8$ to $t-10 . .^{21}$ This predicts that the liquidation probabilities for class B lie between those of classes A and C for both short and long holding periods. Thus, I test whether

$$
\begin{gathered}
\sum_{s=1}^{s=6} p_{s}^{C} \geq \sum_{s=1}^{s=6} p_{s}^{B} \geq \sum_{s=1}^{s=6} p_{s}^{A} \\
\& \\
\sum_{s=8}^{s=10} p_{s}^{A} \geq \sum_{s=8}^{s=10} p_{s}^{B} \geq \sum_{s=8}^{s=10} p_{s}^{C}
\end{gathered}
$$

I find that while classes $C$ and $A$ line up as predicted, class B seems to be inconsistent with the predictions above. Class $\mathrm{C}$ investors are more (less) likely to hold the shares for short (long) holding period than class A investors, 0.622 and $0.613(0.218,0.237)$, respectively. However, class B investors have the lowest holding period for holding periods less than seven years, 0.56, and the highest liquidation probability for holding periods greater than seven years, 0.295 . I interpret these results as largely inconsistent with the uncertain holding period hypothesis.

In addition, I test the commitment device hypothesis: if back-end loads help class B investors stay in a fund, I expect them to have low liquidation probabilities for holding periods where a back-end

${ }^{21}$ I do not include $p_{7}$ since classes provide remarkably similar net expected returns for holding periods of 7 years. 
load applies, which is in the first 6 to 7 years. On the contrary, my results indicate that class B investors are more likely to liquidate within the first 6 (7) years, $0.56(0.70)$. Thus, this result is inconsistent with the commitment device hypothesis.

I interpret this analysis with caution due to some caveats. First, there might be a problem due to the failure of controlling for liquidation shocks that are correlated across investors. The underlying premise of my analysis is that the ex-post holding periods are consistent with the exante ones. This is a reasonable expectation if all the liquidation shocks arrive independently across investors. While the personal liquidation shocks might be independent, there might also be some liquidation shocks at the broader level which might trigger systematic early or late liquidations. To circumvent this problem, I include year and objective style dummies in the model, but the dummies might only capture some of the systematic shocks. Secondly, the interpretation of my results might be contaminated by investors' use of fund-switching programs. These programs allow investors to move assets across funds within the same family without paying the loads. For example, investors are charged back-end loads only if they are leaving the family. If investors frequently switch funds within the family, such programs might shift the estimated distributions of holding periods to the left, and perhaps by different amounts for each class. However, the fact that estimated holding periods of classes $\mathrm{A}$ and $\mathrm{C}$ line up as expected might indicate that these programs do not have dramatic impact on my results. Also, the dynamics of total assets managed in class B depicted in Figure 1 suggest that class B investors are primarily leaving the class rather than switching to the other class Bs of the funds offered by their fund families. The final caveat of this analysis is to use noisy measures of inflows and outflows instead of actual values. It is not immediately apparent why the noise in measures would lead to the specific results I obtain.

\section{Robustness Checks}

\subsection{Differential Taste for Non-Portfolio Characteristics}

In section 6, I suggest that product differentiation occurs largely at the fund level. However, if the taste for some non-portfolio characteristics is correlated with the investor's holding period, each class's investors might systematically value a different set of fund characteristics. Funds targeting a particular class may have fees that are more strongly correlated with the characteristics that their target class value. Since the bias due to unobservable fund attributes in this case would not necessarily equal across classes, I might then find differences in fee sensitivity across classes. Therefore, I investigate whether my results from the flow-fee sensitivity analysis are driven by class B investors' differential taste for some non-portfolio characteristics. I analyze a set of observable characteristics to show that results are unlikely to be driven by differential taste for non-portfolio characteristics.

If tastes are correlated with holding periods, it is not obvious why potential cross-class differences in taste for non-portfolio characteristics would lead to differences in fee sensitivity only between class $B$ and the others. If class B investors are uncertain about their holding period, we would expect them to have weights on characteristics that are appreciated by investors with short and long holding 
periods. Also, if they are long term investors with commitment problems, then we expect them to be similar in their taste to investors with long holding periods. Therefore, if there is any difference in fee sensitivities driven by the differences in taste for non- portfolio characteristics, I expect to observe larger discrepancies between classes $\mathrm{A}$ and $\mathrm{C}$ rather than between class $\mathrm{B}$ and the others.

However, I still consider the possibility that class B investors have a differential taste for some non-portfolio characteristics than do other classes' investors. I examine the relationship between net flow and the year $t-1$ values of my proxies of tax efficiency, fund turnover ratio, family size, total number of funds, and number of funds in different objectives offered by the family. As in Elton et al. [2004], I construct a proxy for tax efficiency by taking income distributions (before expense ratio) as a percentage of net asset value (NAV) and dividing this by its mean value within the same investment objective and year. I use turnover ratio as reported in CRSP as the minimum of aggregated sales or aggregated purchases of securities divided by the average 12-month total net assets of the fund. I include the logarithm of the sum of total assets under family management to proxy for customer services.

I use the same sample used for fee sensitivity analysis and cluster the standard errors by classfund observations. I include the control variables of $t-1$ values of expense ratio, $\operatorname{load}, \log (T N A)$, and performance measures in year $t, t-1$ and square of $t-1$ performance. Results are reported in Table 9. Estimates of the cross-class differences are reported for each variable of interest in columns from (1) to (5). I do not find important differences in taste for these attributes across classes. Only class $\mathrm{C}$ investors seem significantly more attentive to tax efficiencies. Investors in each class similarly prefer big families.

\subsection{Alternative Dependent Variables for Flow-Fee Sensitivity Analysis}

\subsubsection{Inflow}

I repeat the flow-fee sensitivity analysis in (4) using the dependent variable of In flow $i, t$ which is equal to $\$$ In $f l o w_{i, t}$, as defined in (13), divided by TNA $A_{i, t-1}$. Also, I control for Out flowi,t given the mechanical correlation between my measures of dollar outflow and inflow. I report the results in Table 10 both with and without this control variable in columns (1) and (2), respectively.

The results in columns (1) and (2) are remarkably similar because even though there is a negactive relationship between inflow and outflow, as expected, it is insignificant. I find that the coefficients on the interaction terms between expense ratios and class dummies B and $C$ show, in both (1) and (2), that Inflow is significantly less related to expense ratios for class B only, with p-values of 0.021 and 0.018 .

\subsubsection{Market Share}

I propose an alternative empirical model where I use the market share of dollar inflows instead of net flows as the dependent variable. My market share measure, MS Inflowt, is the dollar inflow divided by the total dollar inflows within each class given a year and investment style. I use a similar model in (4) (i.e. Table 5, column (2)). I no longer include $\log \left(T N A_{t-1}\right)$, style and year 
dummies. Also, I include Out $f$ lowt interacted with class dummies, as this variable is related to MS In flow differently for each class. As before, I include fixed effects and cluster the standard errors by class-fund. The results are reported in Table 10, column (3).

Past performance measures are strong predictors of the next year's market share. However, I do not find a nonlinear relationship between MS In flowt and Per $f_{t-1}$. This is consistent with Spiegel and Zhang [2010] who analytically shows that the nonlinear relationship disappears with a market share approach. Also, unlike the regressions with the net flow as the dependent variable, I find that Loadt-1 $_{t}$ and its interaction terms with class B and C dummies are insignificant. This confirms my previous conjecture that load variables in those regressions capture the differences in average growth rates of net flows across classes. Regarding cross class differences in expense ratio sensitivity, I find that, as before, ExpenseRatio $t_{-1} x B$ is significantly positive (p-value of 0.021) contrary to ExpenseRatio $t_{-1} x$ C. In column (4), I drop the logarithm of assets in same class and outflow variables to keep the model simpler. ExpenseRatiot-1 $x B$ in this case is still positive but statistically less significant. However, with this model, the adjusted $R^{2}$ substantially declines to 0.03 from 0.116 , hence the model presented in column (3) seems more appropriate.

\section{Conclusion}

This paper investigates whether mutual fund brokers exploit naïve investors through their complicated fee schedules, as it has been claimed in the marketplace. I document a new finding that the class B fee schedule, which includes a back-end load and high annual fees, mostly performs worse than the other schedules for an investor who knows his/her holding period with certainty. My analysis suggests that while this schedule might appear to be optimal for investors with either uncertain holding periods or long holding periods and commitment problems, brokers seem to use it to exploit naïve investors. 


\section{References}

Anagol, Santosh, Shawn Cole, and Shayak Sarkar. "Understanding the advice of commissions-motivated agents: Evidence from the Indian life insurance market." Review of Economics and Statistics 99.1 (2017): 1-15.

G. Alexander, J.D. Jones, and P.J. Nigro. Mutual fund shareholders: Characteristics, investor knowledge, and sources of information. Financial Services Review, 7(4):301-316, 1998.

D. Avramov and R. Wermers. Investing in mutual funds when returns are predictable. Journal of Financial Economics, 81(2):339-377, 2006.

K.P. Baks, A. Metrick, and J. Wachter. Should investors avoid all actively managed mutual funds? A study in Bayesian performance evaluation. The Journal of Finance, 56(1):45-85, 2001.

B.M. Barber, T. Odean, and L. Zheng. Out of Sight, Out of Mind: The Effects of Expenses on Mutual Fund Flows. The Journal of Business, 78(6), 2005.

G. Belsky and T. Gilovich. Why smart people make big money mistakes-And how to correct them: Lessons from the new science of behavioral economics. Simon and Schuster, 1999.

D. Bergstresser and J. Poterba. Do after-tax returns affect mutual fund inflows? Journal of Financial Economics, 63(3):381$414,2002$.

D. Bergstresser, J.M.R. Chalmers, and P. Tufano. Assessing the costs and benefits of brokers in the mutual fund industry. Review of Financial Studies, 2009.

J. Berk and I. Tonks. Return persistence and fund flows in the worst performing mutual funds. NBER Working Paper, 2007.

J.B. Berk and R.C. Green. Mutual fund flows and performance in rational markets. Journal of Political Economy, 112(6):1269-1295, 2004. ISSN 0022-3808.

S.J. Brown and W.N. Goetzmann. Performance persistence. Journal of finance, 50(2):679-698, 1995. ISSN 0022-1082.

N. Capon, G.J. Fitzsimons, and R. Alan Prince. An individual level analysis of the mutual fund investment decision. Journal of Financial Services Research, 10(1):59-82, 1996.

M.M. Carhart. On persistence in mutual fund performance. Journal of finance, 52(1):57-82, 1997.

B.I. Carlin. Strategic price complexity in retail financial markets. Journal of Financial Economics, 91 (3):278-287, 2009.

G.D. Cashman, D.N. Deli, F. Nardari, and S.V. Villupuram. Understanding the Non-Linear Relation between Mutual Fund Performance and Flows. Working Paper, 2008.

J. Chevalier and G. Ellison. Risk taking by mutual funds as a response to incentives. Journal of Political Economy, 105(6):1167-1200, 1997.

J.J. Choi, D. Laibson, and B.C. Madrian. Why does the law of one price fail? An experiment on index mutual funds. Review of Financial Studies, 23(4):1405, 2010. ISSN 0893-9454.

S.E.K. Christoffersen and D.K. Musto. Demand curves and the pricing of money management. Review of Financial Studies, 15(5):1499, 2002.

Christoffersen, Susan EK, Richard Evans, and David K. Musto. "What do consumers' fund flows maximize? Evidence from their brokers' incentives." The Journal of Finance 68.1 (2013): 201-235.

D. Del Guercio, J. Reuter, and P.A. Tkac. Broker Incentives and Mutual Fund Market Segmentation. 2010. 
S. DellaVigna and U. Malmendier. Contract Design And Self-Control: Theory And Evidence. Quarterly Journal of Economics, 119(2):353-402,2004.

S. DellaVigna and U. Malmendier. Paying not to go to the gym. American Economic Review, 96(3): 694-719, 2006.

J. Dominitz, A.A. Hung, and J.K. Yoong. How Do Mutual Fund Fees Affect Investor Choices? Evidence from Survey Experiments. Working Papers, 2008.

G. Ellison and S.F. Ellison. Search, obfuscation, and price elasticities on the internet. Econometrica, 77(2):427-452, 2009.

G. Ellison and A. Wolitzky. A search cost model of obfuscation. The RAND Journal of Economics 43.3 (2012): 417-441..

Guercio, D.D. and Reuter, J., 2014. Mutual fund performance and the incentive to generate alpha. The Journal of Finance, 69(4), pp.1673-1704.

E.J. Elton, M.J. Gruber, and C.R. Blake. A first look at the accuracy of the CRSP mutual fund database and a comparison of the CRSP and Morningstar mutual fund databases. The Journal of Finance, 56(6):2415-2430, 2001.

E.J. Elton, M.J. Gruber, and J.A. Busse. Are investors rational? Choices among index funds. The Journal of Finance, 59(1):261-288, 2004. ISSN 1540-6261.

F.J. Fabozzi. The handbook of financial instruments. John Wiley \& Sons Inc, 2002. ISBN 0471220922.

Foerster, S., Linnainmaa, J. T., Melzer, B. T., \& Previtero, A. (2017). Retail financial advice: does one size fit all?. The Journal of Finance, 72(4), 1441-1482.

X. Gabaix and D. Laibson. Shrouded Attributes, Consumer Myopia, and Information Suppression in Competitive Markets. Quarterly Journal of Economics, 121(2):505-540, 2006.

D.D. Guercio and P.A. Tkac. Star Power: The Effect of Monrningstar Ratings on Mutual Fund Flow. Journal of Financial and Quantitative Analysis, 43(04):907-936, 2009.

A. Hortacsu and C. Syverson. Product Differentiation, Search Costs, and Competition in the Mu- tual Fund Industry: A Case Study of S\&P 500 Index Funds. Quarterly Journal of Economics, 119 (2):403-456, 2004.

J. Huang, K.D. Wei, and H. Yan. Participation costs and the sensitivity of fund flows to past per- formance. The Journal of Finance, 62(3):1273-1311, 2007.

D. Kahneman and A. Tversky. Prospect theory: An analysis of decision under risk. Econometrica: Journal of the Econometric Society, 47(2):263-291, 1979.

D. Laibson. Golden Eggs and Hyperbolic Discounting. Quarterly Journal of Economics, 112(2):443- 477, 1997.

M. Massa. How do family strategies affect fund performance? When performance-maximization is not the only game in town. Journal of Financial Economics, 67(2):249-304, 2003.

P.R. Milgrom. Good news and bad news: Representation theorems and applications. The Bell Journal of Economics, 12(2):380391, 1981.

Morningstar. Mutual Fund Share Class Limits and Share Class Suitability. 2006.

S. Mullainathan, J. Schwartzstein, and A. Shleifer. Coarse Thinking and Persuasion. Quarterly Journal of Economics, 123(2):577-619, 2008.

V. Nanda, Z.J. Wang, and L. Zheng. Family values and the star phenomenon: Strategies of mutual fund families. Review of Financial Studies, 2004.

V.K. Nanda, Z.J. Wang, and L. Zheng. The ABCs of mutual funds: On the introduction of multiple share classes. Journal of Financial Intermediation, 18(3):329-361, 2009.

J. Rea and B. Reid. Mutual Fund Distribution Channels and Distribution Costs. Investment Company Institute Perspective, 9(3), 2003. 
B. Reid. The 1990s: A Decade of Expansion and Change in the U.S. Mutual Fund Industry. Investment Company Institute Perspective, 6(3), 2000.

E.R. Sirri and P. Tufano. Costly search and mutual fund flows. The Journal of Finance, 53(5):1589- 1622, 1998

M. Spiegel and H. Zhang. Mutual Fund Risk and Market Share Adjusted Fund Flows. Working Papers, 2010.

R. Spiegler. Competition over agents with boundedly rational expectations. Theoretical Economics, 1(2):207-231, 2006.

R. Thaler. Mental accounting and consumer choice. Marketing science, 4(3):199-214, 1985.

R.T. Wilcox. Bargain hunting or star gazing? Investors' preferences for stock mutual funds. Journal of Business, 76(4):645663, 2003. 


\section{APPENDIX}

A. Mutual Fund Distribution Industry The purpose of this section is to describe the evolution of mutual fund sales methods, that is, distribution channels. In the last decade, there have been dramatic changes in how mutual funds are distributed to retail investors. Before 1980, funds sold shares to the retail investors either directly or through an intermediary. Direct sales meant investors approaching the mutual fund company by a 1-800 telephone contact and opening an account. Since there was no investment counsel or service provided, it was also called the "do- ityourself" channel. Fund distribution through an intermediary, on the other hand, involved a fullservice broker who provided advice, assistance, and ongoing service to the investor. Funds sold via an intermediary charged sales charges (i.e. load) to compensate for their services. A decade ago most funds were sold through the intermediary channel.

Starting from the 1990s, there have been several significant changes in the mutual fund distribution industry. The variety of products made available to investors with considerable facility and low cost vastly increased through innovated programs. The most prominent new channel that contributed to the expansion of mutual fund sales in the last decade is the retirement channel, which refers to mutual fund sales through employer sponsored retirement plans (for example, $401(\mathrm{k})$ ) and IRAs. ${ }^{1}$ In addition to the emergence of a new channel, some developments occurred within existing traditional channels as well. Starting from 1992, fund and brokerage companies developed new outlets, called supermarkets (for example, Schwab), offering funds with no loads. As in the traditional direct channel, the supermarket channel did not provide any advice; however supermarkets offered investors a cost effective way of purchasing funds from a number of different families. This has been a major change in the direct channel; an increasing fraction of new sales in the direct channel come from the supermarket channel.

In addition to the innovations in the distribution industry, the SEC adopted a new rule $18 \mathrm{f}-3 \mathrm{in}$ 1995, which provided funds the flexibility to utilize new distribution channels. This rule allowed funds to offer multiple classes where each class, by definition, represents claims on the same underlying portfolio with a different fee arrangement.

Shortly after, full service brokers started new classes, which offered investors alternative methods to pay for sales charges. The most common classes brokers sell is labeled A, B and C. While class $A$ is the class with the traditional sales method, which includes a front load, classes B and C introduced alternative ways to pay for sales charges. Even though multiple class sales strategies were first initiated within the intermediary channel, funds later used separate classes for distribut- ing through different channels; hence multiple class strategy also became a multiple distribution strategy.

It has been common in the intermediary channel that fund manufacturers distributed only their own funds; fund distributors distributed only one manufacturer's funds. However, investors' demands for choice and convenience and distributors' need to appear independent and objective have incentivized intermediaries to initiate a new channel called independent financial advisors (also called "planners"). This channel is served by fee-based, registered investment advisers and not by brokers in securities firms. Financial advisers charge neither a front nor a back-end load, but a small $12 \mathrm{~b}-1$ fee and an additional asset-based fee. ${ }^{2}$ While many planners recommend mutual funds to their clients, some recommend portfolios of planner-selected securities. Also, recently some mutual funds have sold mutual funds in an insurance wrapper through insurance agents. This new emerging channel is called variable annuity.

In short, we can now classify retail channels as retail or retirement. ${ }^{3}$ The retail channel can be decomposed into two groups, direct and intermediary. The direct channel can further be grouped as pure direct (the traditional direct) and supermarket channels. Furthermore, the intermediary channel can be classified as full service broker-dealer, independent, sales representatives at banks and savings institutions and insurance agents.

\footnotetext{
${ }^{1}$ According to the recent ICI reports, an increasing number of household consider their pension plans their primary source of purchasing funds. As a consequence, the portion of assets held in these programs increased from 19 to 30 percent between 1990 and 1999.

${ }^{2}$ Data on asset based fees charged by independent advisors is not available.

${ }^{3}$ The distribution industry also initiated new programs for institutional investors. These programs offer managed accounts which typically "wrap" mutual funds in a service package. Hence, they are commonly called wrap programs. Similar to the independent advisors, these programs charge an asset-based fee rather than traditional loads for their ser- vices. Since minimum investment requirements are generally high, this new channel serves only institutional investors and ultra high net worth individual investors. However, very recently, as initial investment requirements became as low as $\$ 25,000$, wrap accounts also started to compete in the retail segment.
} 
Figure 1: Total Net Assets Managed in Classes A, B and C from 1995 to 2008

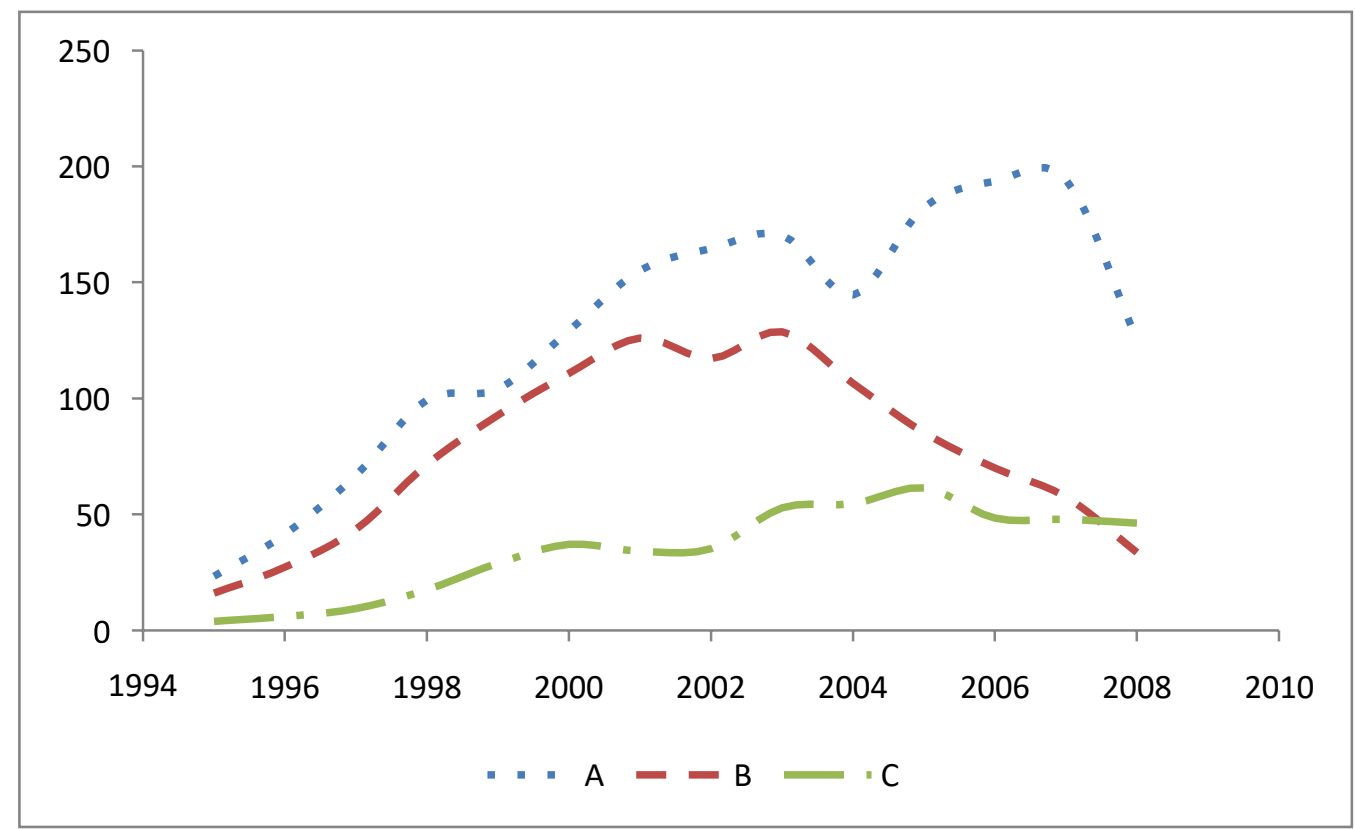

This figure displays the year-end total net assets (TNA), in billions, managed in classes A, B and C. The sample includes the diversified U.S equity mutual funds which offer classes A, B and C between 1995 and 2008. Funds close to new investors are excluded. 
Table 1: Fee Schedules of a Typical A, B and C Classes

\begin{tabular}{|c|c|c|c|c|c|c|}
\hline \multirow{2}{*}{ Class } & \multirow{2}{*}{$12 b-1$} & \multirow{2}{*}{$\begin{array}{c}\text { Management } \\
\text { Fee }\end{array}$} & \multirow{2}{*}{$\begin{array}{c}\text { Expense } \\
\text { Ratio }\end{array}$} & \multicolumn{2}{|c|}{ Front Load } & \multirow{2}{*}{ Back-End Load } \\
\hline & & & & Investment Amount & Load & \\
\hline A & $0.25 \%$ & $0.75 \%$ & $1 \%$ & $\begin{array}{c}<\$ 50,000 \\
\$ 50,000-\$ 100,000 \\
\$ 100,000-\$ 250,000 \\
\$ 250,000-\$ 500,000 \\
\$ 500,000-\$ 1,000,000 \\
>\$ 1,000,000\end{array}$ & $\begin{array}{l}5.75 \% \\
4.50 \% \\
3.50 \% \\
2.50 \% \\
2.00 \% \\
0.00 \%\end{array}$ & $0 \%$ \\
\hline B & $1 \%$ & $0.75 \%$ & $1.75 \%$ & $0.00 \%$ & & $\begin{array}{l}5 \% \text { in year } 1 \\
4 \% \text { in year } 2 \\
3 \% \text { in year } 3 \\
3 \% \text { in year } 4 \\
2 \% \text { in year } 5 \\
1 \% \text { in year } 6\end{array}$ \\
\hline $\mathrm{C}$ & $1 \%$ & $0.75 \%$ & $1.75 \%$ & $0.00 \%$ & & $1 \%$ in year 1 \\
\hline
\end{tabular}

This table provides an example of fee schedules of classes A, B and C for a mutual fund which offers all three classes. 
Table 2: Distribution of Winner Class Across Classes A, B and C

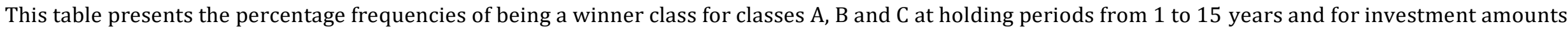

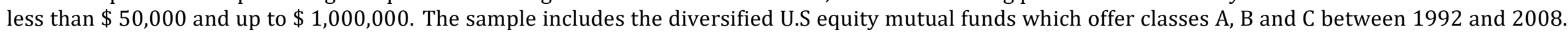

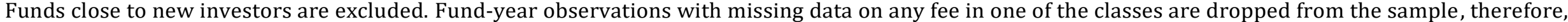

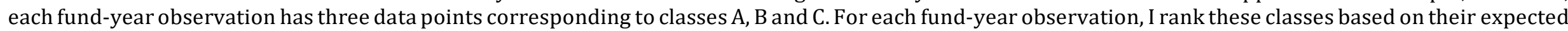

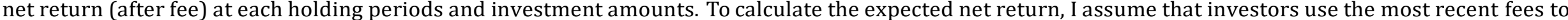

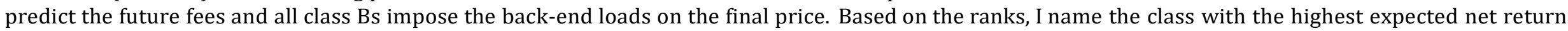
winner class. I report how frequently each class is a winner class at each holding period and investment amount. Numbers represent percentages.

\begin{tabular}{|c|c|c|c|c|c|c|c|c|c|c|c|c|c|c|c|c|}
\hline & Class & 1 year & 2 year & 3 year & 4 year & 5 year & 6 year & 7 year & 8 year & 9 year & 10 year & 11 year & 12 year & 13 year & 14 year & 15 year \\
\hline \multirow[t]{3}{*}{$<\$ 50,000$} & $A$ & 0.06 & 0.15 & 0.22 & 0.60 & 2.05 & 7.15 & 22.19 & 79.31 & 81.49 & 81.73 & 81.92 & 82.01 & 82.05 & 82.07 & 82.09 \\
\hline & $B$ & 0.00 & 0.04 & 0.26 & 0.50 & 1.90 & 6.81 & 35.68 & 10.00 & 17.41 & 17.56 & 17.60 & 17.69 & 17.67 & 17.69 & 17.65 \\
\hline & $C$ & 99.94 & 99.81 & 99.53 & 98.90 & 96.06 & 86.04 & 42.12 & 10.69 & 1.10 & 0.71 & 0.47 & 0.30 & 0.28 & 0.24 & 0.26 \\
\hline \multirow[t]{3}{*}{$\$ 50,000$} & $A$ & 0.06 & 0.15 & 0.22 & 0.67 & 2.61 & 9.35 & 27.75 & 80.65 & 82.44 & 82.70 & 82.81 & 82.87 & 82.89 & 82.91 & 82.93 \\
\hline & $B$ & 0.00 & 0.04 & 0.26 & 0.50 & 1.51 & 6.25 & 32.41 & 9.09 & 16.68 & 16.79 & 16.85 & 16.89 & 16.83 & 16.87 & 16.85 \\
\hline & $C$ & 99.94 & 99.81 & 99.53 & 98.84 & 95.88 & 84.40 & 39.84 & 10.26 & 0.88 & 0.52 & 0.34 & 0.24 & 0.28 & 0.22 & 0.22 \\
\hline \multirow[t]{3}{*}{$\$ 100,000$} & $A$ & 0.06 & 0.24 & 0.30 & 1.92 & 5.37 & 26.55 & 85.97 & 94.38 & 94.70 & 94.83 & 94.94 & 94.98 & 95.00 & 95.02 & 95.02 \\
\hline & $B$ & 0.00 & 0.00 & 0.19 & 0.47 & 1.49 & 5.30 & 6.92 & 3.15 & 4.76 & 4.80 & 4.83 & 4.76 & 4.85 & 4.80 & 4.80 \\
\hline & $C$ & 99.94 & 99.76 & 99.50 & 97.61 & 93.15 & 68.15 & 7.11 & 2.48 & 0.54 & 0.37 & 0.24 & 0.26 & 0.15 & 0.17 & 0.17 \\
\hline \multirow[t]{3}{*}{$\$ 250,000$} & $A$ & 0.11 & 0.30 & 1.98 & 9.87 & 62.25 & 90.76 & 96.47 & 98.69 & 98.77 & 98.84 & 98.86 & 98.86 & 98.88 & 98.88 & 98.88 \\
\hline & $B$ & 0.00 & 0.00 & 0.19 & 0.47 & 0.71 & 0.80 & 1.94 & 0.90 & 0.97 & 0.97 & 1.01 & 0.95 & 0.97 & 0.99 & 0.95 \\
\hline & $C$ & 99.89 & 99.70 & 97.82 & 89.66 & 37.04 & 8.45 & 1.59 & 0.41 & 0.26 & 0.19 & 0.13 & 0.19 & 0.15 & 0.13 & 0.17 \\
\hline \multirow[t]{3}{*}{$\$ 500,000$} & $A$ & 2.63 & 2.56 & 11.68 & 83.69 & 97.16 & 98.36 & 98.79 & 99.07 & 99.03 & 99.05 & 99.05 & 99.05 & 99.05 & 99.05 & 99.05 \\
\hline & $B$ & 0.00 & 0.00 & 0.19 & 0.43 & 0.56 & 0.75 & 0.88 & 0.67 & 0.75 & 0.82 & 0.80 & 0.78 & 0.80 & 0.75 & 0.78 \\
\hline & $C$ & 97.37 & 97.44 & 88.13 & 15.88 & 2.28 & 0.88 & 0.32 & 0.26 & 0.22 & 0.13 & 0.15 & 0.17 & 0.15 & 0.19 & 0.17 \\
\hline \multirow[t]{3}{*}{$\$ 1,000,000$} & $A$ & 12.95 & 10.95 & 87.55 & 98.25 & 98.51 & 98.62 & 99.01 & 99.16 & 99.10 & 99.10 & 99.12 & 99.12 & 99.12 & 99.12 & 99.12 \\
\hline & $B$ & 0.00 & 0.00 & 0.00 & 0.32 & 0.45 & 0.62 & 0.73 & 0.67 & 0.75 & 0.75 & 0.71 & 0.71 & 0.73 & 0.73 & 0.73 \\
\hline & $C$ & 87.05 & 89.05 & 12.45 & 1.42 & 1.03 & 0.75 & 0.26 & 0.17 & 0.15 & 0.15 & 0.17 & 0.17 & 0.15 & 0.15 & 0.15 \\
\hline
\end{tabular}


Table 3: Median of within-Fund Performance Rankings for Each Class

This table reports the median of within fund-year observation rankings of classes A, B and C at holding periods from 1 to 15 years for investment amounts less than $\$ 50,000$ and up to $\$ 1,000,000$. The sample includes the diversified U.S equity mutual funds which offer classes A, B and C between 1992 and 2008 . Funds close to new investors are excluded. Fund-year observations with missing data on any fee in one of the classes are dropped from the sample, therefore each fund-year observation has three data points corresponding to classes A, B and C. For each fund-year observation, I rank these classes in descending order based on their expected net return (after fee) at each holding periods and investment amounts. Class with the best performance is assigned rank of 1 . To calculate the expected net return, I assume that investors use the most recent fees to predict the future fees and all class Bs impose the back-end loads on the final price. I report median of ranks for each class at each holding period and investment amount.

\begin{tabular}{|c|c|c|c|c|c|c|c|c|c|c|c|c|c|c|c|c|}
\hline & Class & 1 year & 2 year & 3 year & 4 year & 5 year & 6 year & 7 year & 8 year & 9 year & 10 year & 11 year & 12 year & 13 year & 14 year & 15 year \\
\hline \multirow[t]{3}{*}{$<\$ 50,000$} & $A$ & 3 & 3 & 3 & 3 & 3 & 3 & 3 & 1 & 1 & 1 & 1 & 1 & 1 & 1 & 1 \\
\hline & B & 2 & 2 & 2 & 2 & 2 & 2 & 2 & 2 & 2 & 2 & 2 & 2 & 2 & 2 & 2 \\
\hline & $C$ & 1 & 1 & 1 & 1 & 1 & 1 & 2 & 2 & 3 & 3 & 3 & 3 & 3 & 3 & 3 \\
\hline \multirow[t]{3}{*}{$\$ 50,000$} & $A$ & 2 & 3 & 3 & 2 & 2 & 3 & 3 & 1 & 1 & 1 & 1 & 1 & 1 & 1 & 1 \\
\hline & B & 3 & 2 & 2 & 3 & 3 & 2 & 2 & 2 & 2 & 2 & 2 & 2 & 2 & 2 & 2 \\
\hline & $C$ & 1 & 1 & 1 & 1 & 1 & 1 & 2 & 2 & 3 & 3 & 3 & 3 & 3 & 3 & 3 \\
\hline \multirow[t]{3}{*}{$\$ 100,000$} & $A$ & 2 & 2 & 2 & 2 & 2 & 2 & 1 & 1 & 1 & 1 & 1 & 1 & 1 & 1 & 1 \\
\hline & B & 3 & 3 & 3 & 3 & 3 & 3 & 2 & 3 & 2 & 2 & 2 & 2 & 2 & 2 & 2 \\
\hline & $C$ & 1 & 1 & 1 & 1 & 1 & 1 & 2 & 2 & 3 & 3 & 3 & 3 & 3 & 3 & 3 \\
\hline \multirow[t]{3}{*}{$\$ 250,000$} & $A$ & 2 & 2 & 2 & 2 & 1 & 1 & 1 & 1 & 1 & 1 & 1 & 1 & 1 & 1 & 1 \\
\hline & B & 3 & 3 & 3 & 3 & 3 & 3 & 3 & 3 & 2 & 2 & 2 & 2 & 2 & 2 & 2 \\
\hline & $C$ & 1 & 1 & 1 & 1 & 2 & 2 & 2 & 2 & 3 & 3 & 3 & 3 & 3 & 3 & 3 \\
\hline \multirow[t]{3}{*}{$\$ 500,000$} & $A$ & 2 & 2 & 2 & 1 & 1 & 1 & 1 & 1 & 1 & 1 & 1 & 1 & 1 & 1 & 1 \\
\hline & B & 3 & 3 & 3 & 3 & 3 & 3 & 3 & 3 & 2 & 2 & 2 & 2 & 2 & 2 & 2 \\
\hline & $C$ & 1 & 1 & 1 & 2 & 2 & 2 & 2 & 2 & 3 & 3 & 3 & 3 & 3 & 3 & 3 \\
\hline \multirow[t]{3}{*}{$\$ 1,000,000$} & $A$ & 2 & 2 & 1 & 1 & 1 & 1 & 1 & 1 & 1 & 1 & 1 & 1 & 1 & 1 & 1 \\
\hline & B & 3 & 3 & 3 & 3 & 3 & 3 & 3 & 3 & 2 & 2 & 2 & 2 & 2 & 2 & 2 \\
\hline & $C$ & 1 & 1 & 2 & 2 & 2 & 2 & 2 & 2 & 3 & 3 & 3 & 3 & 3 & 3 & 3 \\
\hline
\end{tabular}


Table 4: Summary Statistics

This table reports the summary statistics for expense ratio (in \%), year-end total net assets (TNA) (in \$ millions), net flow (\% of TNA), and annual raw return (net of expense ratio) for the funds in my sample. The sample includes the diversified U.S equity mutual funds which offer classes A, B and $C$ between 1992 and 2008. Funds close to new investors are excluded. Expense ratio, TNA and annual raw return are as reported in CRSP. Net flow is the growth in total assets under management net of internal growth as a percentage of previous year-end TNA. Table includes minimum, maximum, median, the $25^{\text {th }}$ and the $75^{\text {th }}$ percentiles of each variable. Statistics are reported for class $\mathrm{A}, \mathrm{B}$ and $\mathrm{C}$ in panels $1,2,3$, respectively.

\begin{tabular}{lcccc}
\hline & $\begin{array}{c}\text { Expense Ratio } \\
(\%)\end{array}$ & $\begin{array}{c}\text { TNA } \\
\text { (\$ millions) }\end{array}$ & $\begin{array}{c}\text { Net Flow } \\
\text { (\% of TNA })\end{array}$ & Annual Return \\
\hline \multicolumn{5}{c}{ Panel 1. Class A } \\
\hline Min & 0.4 & 0.40 & -0.48 & -0.29 \\
P25 & 1.1 & 28.60 & -0.13 & -0.05 \\
P50 & 1.3 & 106.80 & -0.01 & 0.00 \\
P75 & 1.5 & 384.50 & 0.27 & 0.05 \\
Max & 5.1 & 6525.20 & 20.46 & 1.79 \\
& \multicolumn{5}{c}{ Panel 2. Class B } \\
\hline Min & 1.1 & 0.10 & -0.55 & -0.30 \\
P25 & 1.9 & 9.60 & -0.22 & -0.06 \\
P50 & 2.0 & 42.00 & -0.09 & -0.01 \\
P75 & 2.2 & 161.70 & 0.18 & 0.04 \\
Max & 5.8 & 6573.00 & 17.93 & 1.76 \\
& \multicolumn{5}{c}{ Panel 3. Class C } \\
\hline Min & 1.1 & 0.10 & -0.48 & -0.30 \\
P25 & 1.9 & 4.40 & -0.16 & -0.06 \\
P50 & 2.0 & 16.05 & 0.01 & -0.01 \\
P75 & 2.2 & 66.10 & 0.40 & 0.04 \\
Max & 5.8 & 6458.40 & 20.25 & 1.76 \\
\hline
\end{tabular}

:Expense ratio is after any fee waivers 
Table 5: Summary Statistics: Loads

This table reports the summary statistics for front loads for class $A$ and back-end loads for classes $B$ and $C$ in Panels 1, 2 and 3, respectively, for the funds in my sample. The sample includes the diversified U.S equity mutual funds which offer classes A, B and C between 1992 and 2008. Funds close to new investors are excluded. Table displays minimum, maximum, median, the $25^{\text {th }}$ and the $75^{\text {th }}$ percentiles of each variable. Front loads depend on the investor investment amount. Panel 1 presents the summary statistics for front loads at different investment amounts (in columns). These investment amounts correspond to the amounts at which front loads are commonly reduced. Back-end loads are charged upon redemptions within 6 or 7 years and depend on how long investors hold their shares. Panel 2 and 3 report the back-end loads at holding periods from year 1 to 7 .

\begin{tabular}{lccccccc}
\hline \multicolumn{7}{c}{ Panel 1. Class A: Front Loads (in \%) } \\
\hline & $\$ 10,000$ & $\$ 25,000$ & $\$ 50,000$ & $\$ 100,000$ & $\$ 250,000$ & $\$ 500,000$ & $\$ 1,000,000$ \\
\hline Min & 2.5 & 2.5 & 2.5 & 2.5 & 2.0 & 1.0 & 0.0 \\
P25 & 5.3 & 5.3 & 5.0 & 4.5 & 3.5 & 2.5 & 2.0 \\
P50 & 5.8 & 5.8 & 5.5 & 4.5 & 3.5 & 2.5 & 2.0 \\
P75 & 5.8 & 5.8 & 5.8 & 4.8 & 3.8 & 2.8 & 2.0 \\
Max & 5.8 & 5.8 & 5.8 & 5.8 & 5.8 & 5.8 & 5.8 \\
& & & & & & & \\
\hline
\end{tabular}

Panel 2. Class B: Back-End Loads (in \%)

\begin{tabular}{llllllll}
\hline & 1 year & 2 year & 3 year & 4 year & 5 year & 6 year & 7 year \\
\hline Min & 1.0 & 1.0 & 1.0 & 1.0 & 0.0 & 0.0 & 0.0 \\
P25 & 5.0 & 4.0 & 3.0 & 2.5 & 2.0 & 1.0 & 0.0 \\
P50 & 5.0 & 4.0 & 3.0 & 3.0 & 2.0 & 1.0 & 0.0 \\
P75 & 5.0 & 4.0 & 3.0 & 3.0 & 2.0 & 1.0 & 0.0 \\
Max & 6.0 & 5.0 & 5.0 & 5.0 & 5.0 & 5.0 & 5.0 \\
& & & & & & & \\
\hline
\end{tabular}

Panel 3. Class C: Back-End Loads (in \%)

\begin{tabular}{llllllll}
\hline & 1 year & 2 year & 3 year & 4 year & 5 year & 6 year & 7 year \\
\hline Min & 0.5 & 0.0 & 0.0 & 0.0 & 0.0 & 0.0 & 0.0 \\
P25 & 1.0 & 0.0 & 0.0 & 0.0 & 0.0 & 0.0 & 0.0 \\
P50 & 1.0 & 0.0 & 0.0 & 0.0 & 0.0 & 0.0 & 0.0 \\
P75 & 1.0 & 0.0 & 0.0 & 0.0 & 0.0 & 0.0 & 0.0 \\
Max & 4.0 & 4.0 & 3.0 & 2.0 & 1.5 & 1.5 & 1.5 \\
\hline
\end{tabular}


This table reports the mean coefficient estimates and associated standard errors (in parentheses) from panel regressions of annual class-fund net flows on fees and selected fund characteristics. Columns (1)-(4) present results from year 1992 to 2008, and column (5) reports results from year 1992 to 2006. These regressions, except the one reported in column (4), include class-fund fixed effects. The sample covers diversified U.S equity mutual funds which offer classes A, B and C. Fundyear observations with missing data on any variables in one of the classes are dropped from the sample. Funds close to new investors are excluded from the analyses. The dependent variable, NetFlow, is the growth in total assets under management net of internal growth as a percentage of previous year-end TNA. The independent variables are expense ratio, load (equal to the maximum front load for class $\mathrm{A}$, and it's the maximum back-end load for class $\mathrm{B}$ and also for class $\mathrm{C}$ if it has a back end load), logarithm of previous year-end TNA, style-adjusted (i.e. in excess of average fund return in the same objective style) raw return, $\operatorname{Per} f$, of year $t, t 1$ and $t 2$, style-adjusted raw return squared for year $t$-1, logarithm of total family assets held in each class, Log (AssetsinSameClass), logarithm of class age and the monthly standard deviation of the raw return over the previous 24 months. $\mathrm{B}$ and $\mathrm{C}$ are the class dummies which are equal to 1 if it the observation is a class $\mathrm{B}$ and $\mathrm{C}$, respectively. Regressions include interaction terms of class dummies with expense ratio, load and Per $f_{t}$. The dependent variable is winsorized at the $97.5^{\text {th }}$ percentile. Each regression includes year and objective style dummies. Standard errors are clustered by fund. 


\begin{tabular}{|c|c|c|c|c|c|}
\hline & (1) & (2) & (3) & (4) & (5) \\
\hline Expense Ratiot-1 & $\begin{array}{l}-42.45 * * * \\
(13.80)\end{array}$ & $\begin{array}{l}-42.17 * * * \\
(14.39)\end{array}$ & $\begin{array}{l}-40.30 * * * \\
(14.41)\end{array}$ & $\begin{array}{c}-15.29 * * * \\
(4.03)\end{array}$ & $\begin{array}{l}-50.75^{* * *} \\
(15.95)\end{array}$ \\
\hline Expense Ratiot-1 x B & $\begin{array}{l}28.22 \text { ** } \\
(13.45)\end{array}$ & $\begin{array}{l}31.40^{* *} \\
(13.90)\end{array}$ & $\begin{array}{l}31.16^{* *} \\
(14.04)\end{array}$ & $\begin{array}{l}9.05^{* *} \\
(3.88)\end{array}$ & $\begin{array}{l}30.42 \text { ** } \\
(14.99)\end{array}$ \\
\hline Expense Ratiot-1 x C & $\begin{array}{c}14.86 \\
(14.12)\end{array}$ & $\begin{array}{r}14.84 \\
(14.47)\end{array}$ & $\begin{array}{r}10.53 \\
(14.62)\end{array}$ & $\begin{array}{c}3.49 \\
(3.93)\end{array}$ & $\begin{array}{r}17.93 \\
(17.23)\end{array}$ \\
\hline Loadt-1 & $\begin{array}{l}13.79^{*} \\
(8.08)\end{array}$ & $\begin{array}{l}14.59^{*} \\
(8.21)\end{array}$ & $\begin{array}{r}13.40 \\
(8.56)\end{array}$ & $\begin{array}{l}5.57^{* *} \\
(2.48)\end{array}$ & $\begin{array}{r}11.18 \\
(9.24)\end{array}$ \\
\hline Loadt-1 x B & $\begin{array}{l}-28.58 * * * \\
(10.91)\end{array}$ & $\begin{array}{l}-31.16^{* * *} \\
(10.83)\end{array}$ & $\begin{array}{l}-30.40 * * * \\
(11.07)\end{array}$ & $\begin{array}{c}-6.85 * * \\
(3.43)\end{array}$ & $\begin{array}{r}-23.06^{*} \\
(12.32)\end{array}$ \\
\hline Loadt-1 x C & $\begin{array}{l}-23.95^{* *} \\
(11.03)\end{array}$ & $\begin{array}{l}-26.95^{* *} \\
(11.40)\end{array}$ & $\begin{array}{l}-26.25^{* *} \\
(11.51)\end{array}$ & $\begin{array}{c}-26.84^{* * *} \\
(5.41)\end{array}$ & $\begin{array}{r}-22.39^{*} \\
(12.63)\end{array}$ \\
\hline $\log (\mathrm{TNA}) \mathrm{t}-1$ & $\begin{array}{l}-0.37^{* * *} \\
(0.04)\end{array}$ & $\begin{array}{l}-0.38^{* * *} \\
(0.04)\end{array}$ & $\begin{array}{l}-0.38^{* * *} \\
(0.04)\end{array}$ & $\begin{array}{l}-0.08^{* * *} \\
(0.01)\end{array}$ & $\begin{array}{l}-0.38^{* * *} \\
(0.05)\end{array}$ \\
\hline Perft & $\begin{array}{c}0.10 \\
(0.13)\end{array}$ & $\begin{array}{r}0.10 \\
(0.13)\end{array}$ & $\begin{array}{r}0.10 \\
(0.13)\end{array}$ & $\begin{array}{l}0.82^{* * *} \\
(0.15)\end{array}$ & $\begin{array}{r}0.05 \\
(0.15)\end{array}$ \\
\hline Perft-1 & $\begin{array}{l}1.22^{* * *} \\
(0.14)\end{array}$ & $\begin{array}{l}1.23^{* * *} \\
(0.14)\end{array}$ & $\begin{array}{l}1.10^{* * *} \\
(0.15)\end{array}$ & $\begin{array}{l}1.49^{* * *} \\
(0.11)\end{array}$ & $\begin{array}{l}1.13^{* * *} \\
(0.17)\end{array}$ \\
\hline Perft-1 x B & & & $\begin{array}{l}-0.04 \\
(0.13)\end{array}$ & $\begin{array}{l}-0.30 * * * \\
(0.11)\end{array}$ & $\begin{array}{r}0.06 \\
(0.16)\end{array}$ \\
\hline Perft-1 x C & & & $\begin{array}{l}0.41^{* *} \\
(0.19)\end{array}$ & $\begin{array}{l}0.40^{* * *} \\
(0.15)\end{array}$ & $\begin{array}{l}0.46^{* *} \\
(0.22)\end{array}$ \\
\hline Perf2t-1 & $\begin{array}{l}-0.70^{* *} \\
(0.32)\end{array}$ & $\begin{array}{l}-0.68^{* *} \\
(0.32)\end{array}$ & $\begin{array}{l}-0.67^{* *} \\
(0.32)\end{array}$ & $\begin{array}{c}-0.43 \\
(0.39)\end{array}$ & $\begin{array}{l}-0.73^{* *} \\
(0.34)\end{array}$ \\
\hline Perft-2 & $\begin{array}{l}0.27^{* * *} \\
(0.08)\end{array}$ & $\begin{array}{l}0.27^{* * *} \\
(0.08)\end{array}$ & $\begin{array}{l}0.27^{* * *} \\
(0.08)\end{array}$ & $\begin{array}{l}0.43^{* * *} \\
(0.08)\end{array}$ & $\begin{array}{l}0.26^{* * *} \\
(0.08)\end{array}$ \\
\hline Log(AssetsinSameClass)t & $\begin{array}{l}0.15^{* * *} \\
(0.03)\end{array}$ & $\begin{array}{l}0.15^{* * *} \\
(0.03)\end{array}$ & $\begin{array}{l}0.15^{* * *} \\
(0.03)\end{array}$ & $\begin{array}{l}0.04^{* * *} \\
(0.01)\end{array}$ & $\begin{array}{l}0.14^{* * *} \\
(0.03)\end{array}$ \\
\hline Log(Class Age) & $\begin{array}{l}-0.38^{* * *} \\
(0.11)\end{array}$ & & & & \\
\hline Std Devt-1 & $\begin{array}{c}3.20 \\
(2.21)\end{array}$ & & & & \\
\hline B & & & & $\begin{array}{c}0.15 \\
(0.18)\end{array}$ & \\
\hline $\mathrm{C}$ & & & & $\begin{array}{l}0.54^{* * *} \\
(0.15)\end{array}$ & \\
\hline Fixed Effects? & Yes & Yes & Yes & No & Yes \\
\hline Year Dummies? & Yes & Yes & Yes & Yes & Yes \\
\hline Style Dummies? & Yes & Yes & Yes & Yes & Yes \\
\hline Observations & 6489 & 6489 & 6489 & 6525 & 5163 \\
\hline Adjusted $\mathrm{R} 2$ & 0.333 & 0.329 & 0.331 & 0.238 & 0.309 \\
\hline
\end{tabular}

Standard errors in parentheses

${ }^{*} \mathrm{p}<0.10,{ }^{* *} \mathrm{p}<0.05,{ }^{* * *} \mathrm{p}<0.01$ 
Table 7: Summary Statistics: Monthly \$ Net Flow, Inflow and Outflow

This table provides summary statistics on monthly \$ net flow and my measures of monthly inflows and outflows. Panels 1 and 2 report for a sample of diversified U.S equity mutual funds which offer classes A, B and C between 1992 and 2008. Monthly \$ net flow is the monthly growth in total assets under management net of internal growth. Panel 1 presents the percentage frequencies of positive and negative monthly $\$$ net flow. Panel 2 shows the average number of months with positive and negative \$ net flows within a year. Statistics are displayed for full sample, classes A, B and C in columns. Panel 3 reports summary statistics on monthly raw returns, net flow, my measures and actual values of inflow and outflow. Section (i) illustrates what is reported by Cashman et al (2008) based on $N$-SAR data which provides the actual values of inflows and outflows at the fund level, I report my measures of inflows and outflows section (ii) for a similar sample to theirs. My monthly fund inflow (outflow) measure is equal to (absolute value of) net flow divided by the previous month-end TNA if net flow is positive (negative), otherwise it is set to zero. Reported statistics are mean, median, max, minimum, standard deviation, and the $25^{\text {th }}$ and $75^{\text {th }}$ percentiles. Flow variables are winsorized at the $97.5^{\text {th }}$ percentile.

\begin{tabular}{ccccc}
\hline \multicolumn{5}{c}{ Panel 1. Distribution of Positive and Negative \$ Net Flow } \\
\hline & Full Sample & A & B & C \\
\hline \$NetFlow $<0$ & 50.47 & 52.48 & 58.15 & 48.82 \\
$\$$ NetFlow $>0$ & 49.53 & 47.52 & 41.85 & 51.18 \\
\hline
\end{tabular}

Panel 2. Average \# of Months with Positive and Negative \$ Net Flow

\begin{tabular}{ccccc}
\hline & Full Sample & A & B & C \\
\hline NNetFlow $<0$ & 6.24 & 6.43 & 7.13 & 6.06 \\
\$NetFlow $>0$ & 5.76 & 5.57 & 4.87 & 5.94 \\
\hline
\end{tabular}

Panel 3. N-SAR versus My Measures

\begin{tabular}{lccccccc}
\hline & Mean & Median & Max & P75 & P25 & Min & Std Dev \\
\hline i. N-SAR & & & & & & & \\
Raw Return & 0.015 & 0.016 & 1.172 & 0.087 & -0.061 & -0.65 & 0.133 \\
Net Flow & 0.02 & 0.004 & 0.426 & 0.029 & 0.008 & -0.116 & 0.06 \\
Inflow & 0.054 & 0.028 & 0.477 & 0.065 & 0.013 & 0.001 & 0.068 \\
Outflow & 0.034 & 0.023 & 0.395 & 0.04 & 0.013 & 0.000 & 0.037 \\
ii. My Measures & & & & & & & \\
Raw Return & 0.080 & 0.076 & 3.139 & 0.267 & -0.131 & -0.760 & 0.275 \\
Net Flow & 0.010 & 0.001 & 0.250 & 0.020 & -0.011 & -0.093 & 0.044 \\
Inflow & 0.020 & 0.003 & 0.254 & 0.021 & 0.000 & 0.000 & 0.038 \\
Outflow & 0.009 & 0.002 & 0.097 & 0.012 & 0.000 & 0.000 & 0.016 \\
\hline
\end{tabular}


This table shows the mean coefficient estimates from pooled OLS regressions of annual \$ outflows in year t on annual \$ inflows from year $t$ to $t$-10. Panel 2 regressions restrict the coefficients on annual $\$$ inflows from year $t-1$ to $t 1 \theta$ to be positive and add up to 1 . Results are presented for class A, B and C in columns. Sample for these regressions include mutual funds in all objective styles (equity and non-equity) which offer classes A, B and C. Sample periods are from 2001 to 2008 for class A and from 2002 to 2008 for classes B and C. Funds close to new investors are excluded from the analysis. Annual \$ outflow is equal to absolute value of sum of negative monthly net \$ flows in a given year. Monthly $\$$ net flow is the monthly growth in total assets under management net of internal growth. Annual \$ inflow is equal to sum of positive monthly net $\$$ flows in a given year, multiplied by the cumulative monthly return from the end of the month through the year. To calculate the annual \$ inflows and outflows, 10 months of non-missing data on monthly \$ net flows are required. Annual $\$$ inflows and outflows are winsorized at the $97.5^{\text {th }}$ percentile. Each regression includes year and objective style dummies. Standard errors are clustered by fund. 
Panel 1. Regressions with no Restrictions

\begin{tabular}{lccc}
\hline & $\mathrm{A}$ & $\mathrm{B}$ & $\mathrm{C}$ \\
\cline { 1 - 3 } \$ Inflow $t$ & $-0.299 * * *$ & $-0.283 * * *$ & $-0.213 * * *$ \\
\$ Inflow $t-1$ & $0.117 * * *$ & $-0.168 *$ & $0.160 * *$ \\
\$ Inflow $t-2$ & $0.072 * *$ & $0.150 * *$ & 0.044 \\
\$ Inflow $t-3$ & $0.124 * * *$ & $0.083 * *$ & 0.020 \\
\$ Inflow $t-4$ & $0.060 *$ & $0.186 * * *$ & $0.195 * * *$ \\
\$ Inflow $t-5$ & $0.075 * * *$ & $0.126 * * *$ & -0.034 \\
\$ Inflow $t-6$ & $0.051 * *$ & $0.169 * * *$ & $0.098 * *$ \\
\$ Inflow $t-7$ & $0.119 * * *$ & $0.139 * * *$ & $0.126 * *$ \\
\$ Inflow $t-8$ & 0.030 & $0.173 * * *$ & 0.039 \\
\$ Inflow $t-9$ & $0.076 * * *$ & $0.060 * * *$ & 0.065 \\
\$ Inflow $t-10$ & $0.090 * * *$ & $0.093 * * *$ & $0.091 * *$ \\
Year Dummies? & Yes & Yes & Yes \\
Style Dummies? & Yes & Yes & Yes \\
\hline Observations & 2507 & 1481 & 647 \\
Adjusted $R^{2}$ & 0.334 & 0.739 & 0.627 \\
\hline
\end{tabular}

Panel 2. Regressions with Restrictions

\begin{tabular}{lccc}
\hline & $\mathrm{A}$ & $\mathrm{B}$ & $\mathrm{C}$ \\
\hline \$ Inflow $t$ & $-0.372 * * *$ & $-0.433 * * *$ & $-0.296 * * *$ \\
\$ Inflow $t-1$ & 0.202 & 0.0001 & 0.232 \\
\$ Inflow $t-2$ & $0.085 * *$ & 0.053 & $0.079 * *$ \\
\$ Inflow $t-3$ & $0.135 *$ & $0.112 * * *$ & $0.029 * * *$ \\
\$ Inflow $t-4$ & $0.064 * * *$ & $0.121 * * *$ & 0.191 \\
\$ Inflow $t-5$ & $0.074 * * *$ & $0.121 * * *$ & 0.0001 \\
\$ Inflow $t-6$ & $0.053 * * *$ & $0.157 * * *$ & $0.091 * * *$ \\
\$ Inflow $t-7$ & $0.149 *$ & $0.140 * * *$ & $0.160 * *$ \\
\$ Inflow $t-8$ & $0.049 * * *$ & $0.136 * * *$ & $0.031 * * *$ \\
\$ Inflow $t-9$ & $0.085 * * *$ & $0.068 * * *$ & 0.114 \\
\$ Inflow $t-10$ & $0.103 * * *$ & $0.090 * * *$ & $0.074 * * *$ \\
Year Dummies? & Yes & Yes & Yes \\
Style Dummies? & Yes & Yes & Yes \\
\hline Observations & 2507 & 1481 & 647 \\
Log Likelihood & 5733.98 & 4189.66 & 1970.39 \\
\hline$*$ * $0.10 * * p<0.05 * * *<0,01$ & & &
\end{tabular}

${ }^{*} p<0.10,{ }^{* *} p<0.05,{ }^{* * *} p<0,01$ 
Table 9: Differential Taste for Some Non-Portfolio Characteristics

This table reports the mean coefficient estimates and associated standard errors (in parentheses) from pooled OLS regressions of annual class-fund net flows on selected fund characteristics. The sample covers diversified U.S equity mutual funds which offer classes A, B and C from 1992 to 2008 . Funds close to new investors are excluded from the analyses. The dependent variable, NetFlow, is the growth in total assets under management net of internal growth as a percentage of previous year-end TNA. The key independent variables are income yield, turnover ratio, number of funds offered by the family, number of funds offered by the family in distinct objective styles and the logarithm of family TNA. Income yield is the income distributions (before expense ratio), as a percentage of net asset value, divided by its mean value across funds in the same objective style. B and C are the class dummies which are equal to 1 if it the observation is a class B and C, respectively. Regressions include interactions terms of class dummies with key independent variables. Regressions also include control variables of expense ratio, load (equal to the maximum front load for class $\mathrm{A}$, and it is the maximum back-end load for class $B$ and also for class $C$ if it has a back end load), logarithm of previous year-end TNA, style-adjusted raw return (i.e. in excess of average fund return in its objective style), $\operatorname{Per} f$, of year $t, t 1$ and $t 2$, and style-adjusted raw return squared for year $t$ 1.Dependent variable is winsorized at the $97.5^{\text {th }}$ percentile. Each regression includes year and objective style dummies. Standard errors are clustered by fund. Estimated coefficients on control variables are not reported for expositional purposes. 


\begin{tabular}{|c|c|c|c|c|c|}
\hline & (1) & (2) & (3) & (4) & (5) \\
\hline Income Yield $t-1$ & $\begin{array}{c}-0.02 \\
(0.04)\end{array}$ & $\begin{array}{c}-0.07 \\
(0.05)\end{array}$ & $\begin{array}{c}-0.04 \\
(0.05)\end{array}$ & $\begin{array}{c}-0.07 \\
(0.04)\end{array}$ & $\begin{array}{c}-0.04 \\
(0.05)\end{array}$ \\
\hline Income Yield $t_{-1} \mathrm{xB}$ & $\begin{array}{c}-0.11 \\
(0.08)\end{array}$ & & & & \\
\hline Income Yield $t_{t-1} \mathrm{XC}$ & $\begin{array}{c}-0.16 * * \\
(0.07)\end{array}$ & & & & \\
\hline Turnover Ratio $_{t}-1$ & $\begin{array}{c}0.03 \\
(0.04)\end{array}$ & $\begin{array}{c}-0.03 \\
(0.04)\end{array}$ & $\begin{array}{c}0.01 \\
(0.03)\end{array}$ & $\begin{array}{c}0.03 \\
(0.04)\end{array}$ & $\begin{array}{c}0.01 \\
(0.03)\end{array}$ \\
\hline Turnover Ratio $t_{1} \mathrm{xB}$ & & $\begin{array}{c}0.11 * \\
(0.06)\end{array}$ & & & \\
\hline Turnover Ratio $t \_1 \mathrm{XC}$ & & $\begin{array}{l}0.09 \\
(0.09)\end{array}$ & & & \\
\hline \# of Funds & $\begin{array}{c}0.0009 \\
(0.002)\end{array}$ & $\begin{array}{c}0.0009 \\
(0.002)\end{array}$ & $\begin{array}{l}0.001 \\
(0.001)\end{array}$ & & \\
\hline \# of FundsxB & & & $\begin{array}{l}0.0003 \\
(0.0015)\end{array}$ & & \\
\hline \# of FundsxC & & & $\begin{array}{r}-0.0006 \\
(0.002)\end{array}$ & & \\
\hline \# of Funds in Distinct Styles & $\begin{array}{c}0.003 \\
(0.007)\end{array}$ & $\begin{array}{c}0.002 \\
(0.007)\end{array}$ & & $\begin{array}{l}0.005 \\
(0.006)\end{array}$ & \\
\hline \# of Funds in Distinct StylesxB & & & & $\begin{array}{l}0.004 \\
(0.008)\end{array}$ & \\
\hline \# of Funds in Distinct StylesxC & & & & $\begin{array}{r}-0.0003 \\
(0.009)\end{array}$ & \\
\hline $\log (\text { Family TNA })_{t-1}$ & & & & & $\begin{array}{l}0.03 * \\
(0.02)\end{array}$ \\
\hline $\log (\text { Family TNA })_{t} 1 \mathrm{xB}$ & & & & & $\begin{array}{c}-0.01 \\
(0.02)\end{array}$ \\
\hline $\log (\text { Family TNA })_{t-1 \mathrm{xC}}$ & & & & & $\begin{array}{c}-0.02 \\
(0.02)\end{array}$ \\
\hline Fixed Effects? & No & No & No & No & No \\
\hline Year Dummies? & Yes & Yes & Yes & Yes & Yes \\
\hline Style Dummies? & Yes & Yes & Yes & Yes & Yes \\
\hline Controls? & Yes & Yes & Yes & Yes & Yes \\
\hline Observations & 978 & 978 & 2130 & 978 & 2041 \\
\hline Adjusted $R^{2}$ & 0.304 & 0.303 & 0.265 & 0.302 & 0.266 \\
\hline
\end{tabular}

Standard errors in parentheses

${ }^{*} p<0.10,{ }^{* *} p<0.05,{ }^{* * *} p<0.01$ 
Table 10: Fee Sensitivity Regressions with Alternative Dependent Variables

This table reports the mean coefficient estimates and associated standard errors (in parentheses) from fixed effects regressions of annual fund inflows, or market share of \$ inflows, on fees and selected fund characteristics. The sample covers diversified U.S equity mutual funds which offer classes A, B and C from 1992 to 2008 . Funds close to new investors are excluded from the analyses. Columns (1) and (2) include the dependent variable of annual inflow, which is the sum of positive monthly net $\$$ flow in a given year, divided by the previous year-end TNA. The dependent variable in columns (3) and (4) is MSIn flow, which is the annual \$ inflow divided by the total of annual dollar inflows within each class given a year and objective style. The independent variables include expense ratio, load (equal to the maximum front load for class A and maximum back-end load for class B and also for class $\mathrm{C}$ if it has a back end load), logarithm of previous year-end TNA, style-adjusted raw return (i.e. in excess of average fund return in its objective style), $\operatorname{Per} f$, of year $t, t 1$ and $t 2$, style-adjusted raw return squared for year $t \quad 1$, logarithm of total family assets held in each class and annual outflow in year $t$. Annual outflow is equal to is the absolute value of sum of negative monthly net $\$$ flow in a given year, divided by the previous year-end TNA. B and $\mathrm{C}$ are the class dummies which are equal to 1 if it the observation is a class $\mathrm{B}$ and $\mathrm{C}$, respectively. The regressions include interactions of class dummies with expense ratio, load and outflow. Annual inflow and outflows are winsorized at the $97.5^{\text {th }}$ percentile. Regressions reported in columns (1) and (2) include year and objective style dummies. Standard errors are clustered by fund. 


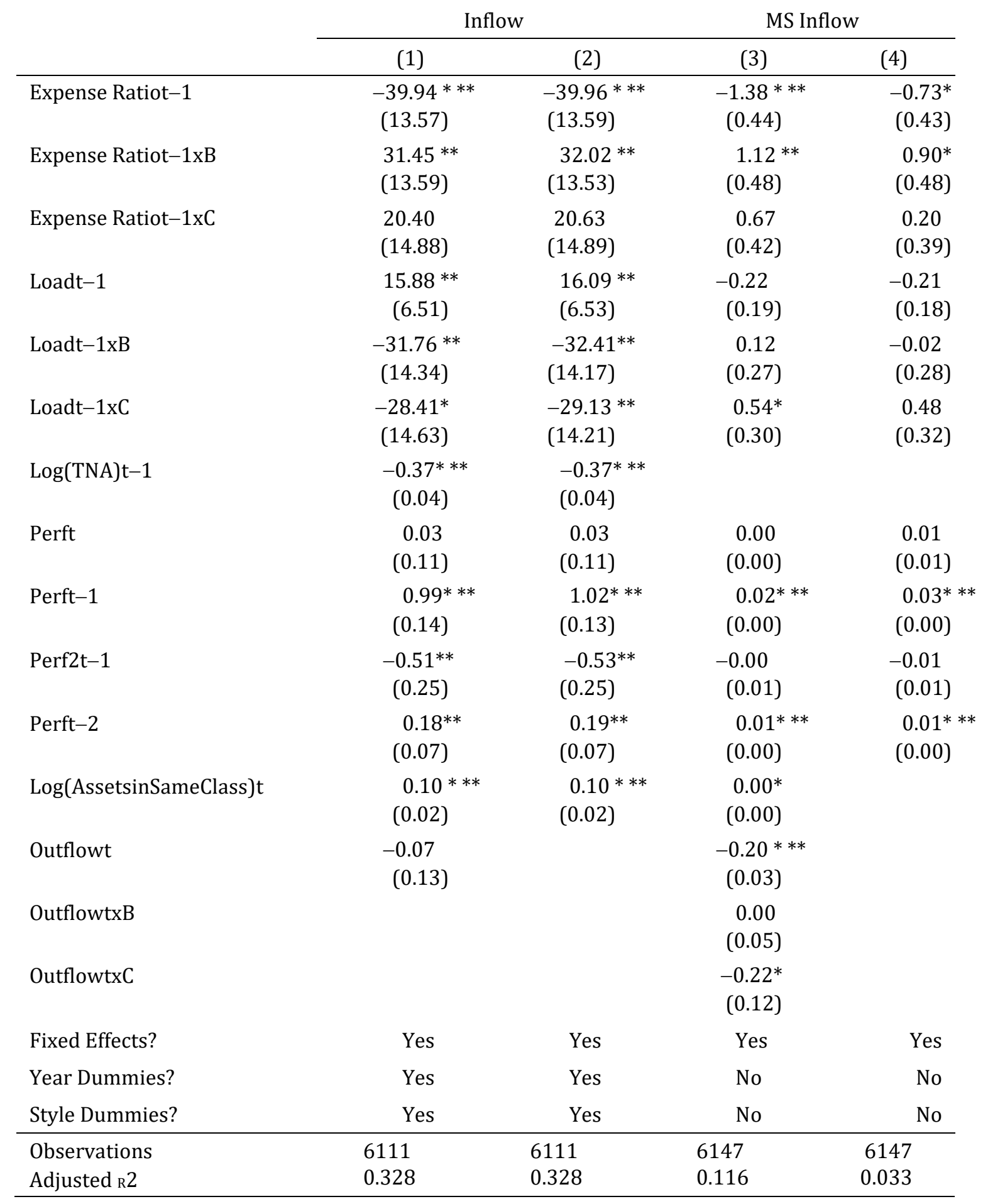

